\title{
Epileptiform activity in the limbic system
}

\section{Mauro, Schneider, Oliveira ${ }^{1}$, Luis Fernando, Pacheco, Otalora ${ }^{2}$, Carlos, Fernando, Mello ${ }^{3}$, Esper, Abrao, Cavalheiro ${ }^{4}$, Emilio, Rafael, Garrido-Sanabria ${ }^{2}$}

${ }^{I}$ Federal University of Pampa at Itaqui, Itaqui 97650-000, RS, Brazil, ${ }^{2}$ Department of Biological Sciences at the University of Texas at Brownsville and Center for Biomedical Studies, 80 Fort Brown, Brownsville, Texas 78520, USA, ${ }^{3}$ Department of Physiology and Pharmacology, Center of Health Sciences, Federal University of Santa Maria, Santa Maria 97105-900, RS, Brazil, ${ }^{4}$ Laboratory of Experimental Neurology, Department of Neurology and Neurosurgery, Federal University of Sao Paulo, São Paulo 04023-900, SP, Brazil

\section{TABLE OF CONTENTS}

\section{Abstract}

2. Introduction

3. Models of convulsions versus models exhibiting recurrent spontaneous seizures

3.1. Chronic epilepsy models with limbic epileptogenesis

3.2. Electrically-induced animal models to investigate MTLE

3.3. Self-sustained limbic status epilepticus models

3.3.1. In vivo epileptiform activity in hippocampus during pilocarpine-induced status epilepticus

3.3.2. In vivo epileptiform activity during pilocarpine-induced spontaneous recurrent seizures

3.3.3. In vitro epileptiform activity in slices obtained from pilocarpine-treated epileptic animals

3.3.4. In vitro models of acute epileptiform activy in limbic structures from normal animals

4. Genetic versus acquired channelopathies

5. MTLE as an acquired channelopathy

5.1. Potassium channels

5.2. Voltage-gated sodium channels

5.3. Voltage-gated calcium channels

5.4. Cyclic nucleotide-regulated channels

6. Summary and perspectives

7. Acknowledgments

8. References

\section{ABSTRACT}

Mesial temporal lobe epilepsy (MTLE) is a common neurological disorder characterized by hyperexcitability of limbic structures. Studies in epileptic patients and animal models of MTLE indicate that epileptiform activity arise primarily from limbic areas (e.g. hippocampus) with secondary propagation to cortical areas. A wealth of evidence indicates that epileptiform activity is associated with complex patterns in the expression and function of ion channels, receptors and transporters. Accordingly, several studies portrait MTLE as a posttranscriptional acquired channelopathy. The present review describes the most common features of epileptiform activity emerging from animal models of limbic epileptogenesis and critically discusses the supporting evidence that MTLE is a complex acquired channelopathy.

\section{INTRODUCTION}

Epilepsy is a common chronic neurological disorder characterized by recurrent unprovoked seizures (1). These seizures are transient signs and/or symptoms of abnormal, excessive or synchronous neuronal activity (abnormal electrical discharges) in the brain $(2,3)$. Epilepsy is a major health problem that affects $2 \%$ of the general population posing tremendous challenges to modern medicine. Although a large number of antiepileptic drugs (AEDs) that suppress or prevent seizures are now available, about $30-40 \%$ of the patients, children as well as adults, remain resistant to drug treatment. Accordingly, pharmacoresistance is present in about $30 \%$ of patients suffering mesial temporal lobe epilepsy (MTLE), one of the most common causes of acquired partial epilepsy, defined by the occurrence of either simple partial or complex 
partial seizures (4). These patients become candidates for surgical resection of the epileptogenic area, in most cases located in the limbic system (i.e. hippocampus and parahippocampal regions) (5). Accordingly, ameliorating epileptogenesis and solving the problem of medical intractability are unmet medical challenges. "Epileptic phenotypes" at neuronal and network levels may ultimately emerge from small, but critical alterations in ion channels or receptors. During the process of epileptogenesis, seizurerelated functional and structural reorganizations of neuronal circuits lead to a form of maladaptative neuroplasticity characterized by hyperexcitability of glutamatergic neurons and defective inhibition $(6,7)$.

Interictal spikes are periodic, very brief bursts of neuronal activity that are observed in the electroencephalogram of patients with chronic epilepsy (8). Classical studies indicate that the electrophysiological correlate of interictal spikes recorded by surface and deep brain electrodes is a paroxysmal depolarization shift (PDS) of the membrane potential when recording of electrical activity is performed simultaneously with intracellular microelectrodes in neurons located in the epileptogenic area $(9,10)$. Bursts of action potentials at high frequency are triggered above membrane threshold during the PDS phenomena, which are associated with polyspiking "epileptiform" activity of network neurons located in the same area (10). Different degrees of epileptiform activity are relatively preserved across different epilepsy models and have been considered a sign of hyperexcitability. Although the eletrophysiological signature of hyperexcitability follows this stereotyped pattern of electrical activity, the mechanisms that transform relatively normal neuronal networks into "epileptogenic" areas are quite complex, and remain not completely understood. In the last decades, investigators have focused on determining how abnormalities in intrinsic properties and synaptic functions contribute to epileptogenesis in an effort to develop comprehensive therapies for the pharmacological management of epilepsy. Indeed, molecular and functional aberrations of ion channels and receptors ("channelopathies") at somatic and dendritic locations have been recently reported as underlying pathogenic mechanisms leading to neuronal hyperexcitability and abnormal postsynaptic integration in experimental and human epilepsy $(11,12)$. These seizure-related abnormalities in the expression of ion channels are considered a key determinant of epileptogenesis and medical intractability. Epileptogenesis refers to the complex molecular and cellular pro-epileptic transformations that are triggered in the normal brain tissue by the initial brain insult (i.e., status epilepticus, traumatic brain injury, encephalitis and meningitis, etc.) leading to increased cellular and network excitability and the emergence of recurrent spontaneous seizures (13). As indicated by Jacobs et al (2009), the concept of a "latent" or "silent" period in humans and animal models of MTLE has been useful to describe this transition. Moreover, epileptogenesis may also develop during the progression of the disease triggered by recurrent seizures and underlying molecular and cellular disturbances. Hence, epileptogenesis is considered to include both the initial development of the epileptic state and the seizure-related abnormalities during the progression of the disease. Elucidation of the precise mechanisms responsible for epileptogenesis may provide a comprehensive strategy to develop preventive measures to arrest pro-epileptic changes and to treat epilepsy.

Early or preventive treatment remains a polemic issue in pharmacotherapy of epilepsy. In this regard, some of the major challenges of epileptology are (a) to reliably determine whether a patient will develop epilepsy after suffering a brain insult (i.e., status epilepticus, traumatic brain injury) and (b) to identify whether a patient suffering epilepsy will develop refractory epilepsy. Meeting these challenges is a high priority because early initiation of aggressive therapy has been proposed as a rational approach that may improve outcome and overall quality of life $(14,15)$. These challenges are associated with the need of effective biomarkers of the disease (e.g., biomarkers of intractability or epileptogenesis) and a comprehensive assessment of potential "acquired" and "genetic" risk factors to identify patients in an early stage of the disease or at high risk to progress to pharmacoresistance. There are no biomarkers available to guide neurologists in the identification of these problems with confidence (14-18). In some cases, syndromic classification and clinical evolution of the disease have allowed to predict intractability $(14,17)$. In an attempt to identify patients at risk for medical intractability, Kwan and Brodie (2000) performed a prospective study involving 525 patients (age, 9 to 93 years) who were given a diagnosis, treated, and followed up for 2 to 16 years. These authors concluded that patients who have many seizures before therapy, or who have an inadequate response to initial treatment with antiepileptic drugs are likely to have refractory epilepsy (18). However, it remains unclear which specific subset of molecular, neuroimaging, electrographic and clinical biomarkers has a predictive power of determining intractability.

Surgery for refractory focal epilepsies has been established as a promising treatment option. Technological advances in multimodal neuroimaging (i.e. fMRI and PET) and electroclinical evaluation have considerably improved preoperative assessments, safety and outcomes of surgical procedures for the treatment of refractory epilepsy (19). However, the current resolution of neuroimaging tools is not adequate to identify subtle cellular and circuit structural abnormalities underlying seizure generation in some cases of intractable focal epilepsy without major neuroimaging structural correlates (e.g. cerebral cortical disgenesis) (20). Furthermore (21), these methods are unable to detect molecular changes at the level of receptors, ion channels and transporters ("molecular determinants of refractoriness") that may constitute potential biomarkers for early diagnosis of pharmacoresistance. A major advance in this area was the introduction of in vivo $\left({ }^{11} \mathrm{C}\right)$ flumazenilpositron emission tomography $\left({ }^{11} \mathrm{C}\right) \mathrm{FMZ}$-PET, an approach that has allowed the detection of reductions of central benzodiazepine receptors in lesional and perilesional areas in epileptic patients (22-24). This approach which offers an in vivo assessment of potential seizure-related downregulation of $\mathrm{GABA}_{\mathrm{A}}$ receptors has been successfully 
combined with other diagnostic tools including, 2-deoxy2- (18F)fluoro-d-glucose (FDG) PET, and electrocorticographic $(\mathrm{ECoG})$ to provide a comprehensive evaluation of patients (20). However, expansion of these potentially diagnostic tools of refractory epilepsy requires a better understanding of molecular biomakers of epilepsy and the expansion of the repertoire of radioactive ligands to reliably identify molecular dysfunctions associated with a risk for refractory epilepsy. In addition, advances in pharmacogenomics and in our understanding of the time course of molecular changes associated with epileptogenesis may provide new avenues to elucidate the basic mechanisms of pharmacoresistance and to elaborate useful predictive tools. Many different experimental models have been developed in order to investigate the basic mechanisms of epilepsy and the challenges posed by medical refractoriness. In this review, we will briefly describe some of these models, with emphasis on MTLE which is a form of epilepsy that critically affects the limbic system. Furthermore, we will describe the major electrophysiological features of the epileptiform activity in structures of the limbic system as well as the molecular alterations in ion channels and receptors that may support the notion that MTLE is a complex form of acquired channelopathy.

\section{MODELS OF CONVULSIONS VERSUS MODELS EXHIBITING RECURRENT SPONTANEOUS SEIZURES}

For many years, acute seizure models have played an essential role in epilepsy research including the screening and development of new antiepileptic drugs. Studies in acute animal models allowed the discovery of the PDS as a cellular correlate of surface epileptiform activity (i.e., interictal spikes) (10). Traditional acute models induced in otherwise normal animals have been instrumental in early investigations related to the cellular basis of ictal discharge and termination. In these models, seizures are induced by either an electrical stimulation or a convulsant agent in non-epileptic "normal" mice, i.e. the maximal electroshock seizure (MES) (25-27), the maximal electroshock seizure threshold (MEST) test (28), the subcutaneous pentylenetetrazol seizure test (29), and the intravenous pentylenetetrazol seizure test (30-32). These tests can be used to characterize anticonvulsant and/or proconvulsant properties of compounds in mice in drugscreening programs (29,33-38). Although the parameters of these tests are optimized for mice, similar tests, with some modifications, can be used with rats. Interestingly, the vast majority of these acute models does not induce convulsive activity in the limbic system. Although these models are still used as a fast track screening for antiepileptic drugs, acute convulsions are induced in a "normal" brain which do not express the pathogenic features of chronic epilepsy. Compelling evidence indicates that molecular targets for antiepileptic drugs can be altered during the process of epileptogenesis (12,199-204,230-237). In addition, networks are remodeled due to seizure-mediated neuronal death and synaptic reorganizations. Furthermore, the seizures in these models can be used for testing of antiepileptic drug effects. A comparison of the pharmacology of chronic models with models of acute (reactive or provoked) seizures in previously healthy (nonepileptic) animals, such as MES, demonstrates that drug testing in chronic models of epilepsy yields data which are more predictive of clinical efficacy and adverse effects, so that chronic models should be used relatively early in drug development to minimize false positives (39). Accordingly, new rational paradigms adopted by the pharmacological industry include pre-clinical testing of potentially antiepileptic and disease-modifying compounds in chronic animal models of epilepsy. Interestingly, the models that are now considered the gold standard for the pharmacological industry are animal models of MTLE in which epileptiform activity originates in the limbic system (40-42).

The advantage of chronic models in the development of novel antiepileptic drugs has been emphasized after the discovery of levetiracetam (namely Keppra ${ }^{\circledR}$ ), a new wide spectrum antiepileptic drug which is highly efficient as monotherapy or adjunctive therapy of several epileptic syndromes $(41,43-56)$. Levetiracetam is an antiepileptic drug devoid of anticonvulsant activity in the MES and pentylenetetrazole seizure tests, in both mice and rats. This contrasts a potent seizure suppression in genetic and kindled mice and rats and against chemoconvulsants inducing partial seizures in rats (57). The highly selective action in "epileptic" animals distinguishes levetiracetam from classic and other new AEDs that have nearly equipotent effects in normal and "epileptic" animals (58).

\subsection{Chronic epilepsy models with limbic epileptogenesis}

Human MTLE is characterized by maladaptive changes in neuronal networks including neuroanatomical changes (i.e., neuronal loss, synaptic reorganization) and molecular abnormalities (i.e. abnormal expression of ion channels, receptors and transporters). Therefore, seizurerelated rearrangements of the neuronal circuits and and dynamic changes underlying epileptogenesis in human epilepsy is definitely better resembled by chronic models of MTLE. Accordingly, several animal models have been developed to investigate basic mechanisms underlying epileptogenesis. There are two popular MTLE models, which are known and characterized by the method of MTLE induction: (a) focal electrical stimulation and (b) systemic or intrahippocampal administration of neurotoxins (i.e., kainic acid and pilocarpine) leading, in most cases, to status epilepticus. In addition, a rare genetic model of MTLE (Ihara's epileptic rat) has been developed by successive mating and selection from an inherited cataract rat (59). This model exhibits genetically programmed neuronal microdysgenesis in the hippocampus which has been causally related to the recurrent spontaneous seizures that affected animals develop $(59,60)$.

\subsection{Electrically-induced animal models to investigate MTLE}

A number of variants of electrically-induced models have been described using different stimulation protocols and brain areas. These models can be classified according to whether electrical stimulation protocols induce (a) kindling or (b) electrically-induced self-sustained 
"limbic" status epilepticus (SSLSE). In general, these models have been developed by stimulation of limbic structure (i.e., hippocampus, amygdala). The kindling model was originally proposed by Goddard and colleagues in 1960 after stimulation of the hypothalamus and amygdala $(61,62)$, who broadly defined it as " a relatively permanent alteration in brain function which results from repeated electrical or chemical stimulation and culminates in the appearance of electrographic and behavioral convulsions whenever the original stimulus is reapplied" (61). The word kindling is a metaphor: the increase in response to small stimuli is similar to the way small burning twigs can produce a large fire $(61,63-65)$. This concept applies not only to electrically- but also to chemically-induced decreases in threshold for afterdischarge and seizures, and more broadly as circuit modifications and reduced threshold for hyperexcitability triggered by endogenously-generated abnormal electrical activity (i.e. seizures). In fact, the assertion that "seizure begets seizures" fits very well with this epileptogenesis process, implying long-lasting and dynamic reorganization of neuronal circuits in epileptiform activity $(61,66-68)$. Mechanisms related to the induction of kindling, were also proposed as a pathological extreme in a continuous array of mechanisms (plasticity-pathology continuum model) (69) responsible for neuronal plasticity (i.e., long-term potentiation of synaptic strengths) (69-73). Although it has been reported that repeated seizure stimulation can result in neuroplastic rearrangements of the limbic circuits (limbic epileptogenesis), spontaneous seizures are rare and not universal across laboratories or species. Therefore, there is currently no consensus in the literature whether kindling causes spontaneous seizures or not $(39,74-81)$.Moreover, it is a matter of significant debate whether experimental results obtained in kindled animals apply to humans with epilepsy (74,75). (74) Although kindling allows the researcher to control and induce epileptiform activity upon stimulation, the low incidence of spontaneous recurrent seizures has prompted scientists to question whether this model produces a true epileptic state (75). It has been proposed that the neuronal alterations produced by kindling, including cell loss and aberrant axonal sprouting, are relatively mild and may not be sufficient to mediate epileptogenesis (82-85). Moreover, it is also not established whether neuronal damage and circuit reorganization observed in kindling is the result of, and not the cause of seizures.

\subsection{Self-sustained limbic status epilepticus models}

In addition to kindling, continuous electrical stimulation of limbic structures including hippocampus (86-90) and amygdala (91-93) has been used to trigger selfsustained limbic status epilepticus (SSLSE). Hippocampal stimulation-induced SSLSE is characterized by intense, but intermittent motor seizure activity, like that seen with kindled motor seizures and nearly continuous 'limbic' behavioral seizures, identical to those seen after low doses of kainic acid or during the early stages of kindling (90). The presence of synchronous, stimulus-independent seizure activity bilaterally in the hippocampi during stimulation precedes the establishment of SSLSE after hippocampal stimulation. Once established, SSLSE can persist for several hours and is followed by chronic neuropathological changes reminiscent of hippocampal sclerosis encountered in epileptic patients (89). It has previously been shown that prolonged (60-min) low-intensity electrical stimulation of a kindled focus in the basolateral nucleus of the amygdala of Wistar rats can result in the development of SSSE with predominantly partial seizures and subsequent brain damage in the ipsilateral hemisphere (91). SSLSE initiates a cascade of events that lead to the development of spontaneous seizures in stimulated animals. Histologic examination of the amygdala and hippocampus from animals subjected to SSLSE revealed neuronal loss in the amygdala, hippocampus, and surrounding cortical areas, as well as mossy fiber sprouting in the dentate gyrus $(89,93)$. In vitro studies using hippocampal slices taken from SSLSE epileptic have shown abnormal excitatory and inhibitory neurotransmission in CA1 area (86-88) . Using extracellular and intracellular recording techniques in brain slice preparations from post-SSLSE model of chronic MTLE (1-7 months following SSLSE) these authors described hyperresponsiveness of the CA1 and dentate gyrus areas when compared to control tissue. "Epileptic" hyperresponsiveness was characterized by 2 or more population spikes elicited by a stimulus strength giving rise to maximal-amplitude population spikes. Control tissue never exhibited $>2$ population spikes in either CA1 or dentate gyrus in response to similar stimuli (94). Moreover, monosynaptic excitatory postsynaptic potentials (EPSPs) evoked in CA1 pyramidal cells in post-SSLSE tissue were always longer than those evoked in control tissue, irrespective of whether hyperresponsiveness was present or not. EPSPs elicited by stimulus subthreshold for action potentials in post-SSLSE and in control slices and matched in amplitude had a statistically longer duration in the postSSLSE slices (88).

Induction of status epilepticus (SE) is considered a reliable strategy to trigger persistent abnormalities (epileptogenesis) resulting in a chronic epileptic condition. Although electrically-induced SSLSE has been adopted in several epilepsy research laboratories, the most popular models are the kainic acid and the pilocarpine model of MTLE which are based on the induction of SE and subsequent epileptogenic changes leading to spontaneous recurrent seizures. There are different variants of these models according to the route and area of administration, doses, and combination with other excitotoxins. For instance, kainic acid, a powerful neurotoxic analogue of glutamate $(95,96)$, has been administered systemically $(97)$, intraventricularly (98) or intracerebraly (e.g., intrahippocampal and intra-amydgaloid microinjection) (99-103) to induce focal and secondarily generalized SE and persistent limbic neuropathology, limbic hyperexcitability and recurrent spontaneous seizures $(104,105)$. Accordingly, the kainic acid model is considered an important tool to investigate MTLE (106). Surface and depth electroencephalogram (EEG) recordings following intravenous injections of $1 \mathrm{mg} / \mathrm{kg}$ kainic acid reveal the presence of high frequency oscillations and spikes in the hippocampus, without propagation to other structures (107). When injected at doses above $4 \mathrm{mg} / \mathrm{kg}$, kainic acid induces electrical seizures in limbic structures, similar to 
those seen in MTLE. Kainic acid $(0.1$ to $1.0 \mu \mathrm{M})$ also induces spontaneous epileptiform spikes, originating in CA3, and increased evoked potentials in hippocampal slices in vitro (108). Moreover, hippocampal slices prepared from kainic acid-treated chronic epileptic rats reveal signs of hyperexcitability (i.e., hyperresponsiveness, evoked and spontaneous epileptiform activity) in limbic structures. For instance, about $55 \%$ of the CA1 pyramidal cells, in slices where the CA3/CA4 region has been lesioned using intracerebroventricular kainic acid injection, respond with bursts of action potentials (synchronous hyperexcitability) after orthodromic excitation, which was associated with a loss of synaptic inhibition (109). Supporting the defective inhibition hypothesis, Nakajima et al, (1991) reported weakened interconnections between pyramidal cells and interneurons in hippocampal slices dissected 2-4 weeks following bilateral intraventricular KA injections (110). Hippocampal slices from animals that had previously experienced continuous hippocampal stimulation-induced SSLSE demonstrated an increased excitability relative to slices from control animals as evidenced by epileptiform bursting in increased extracellular potassium $\left(\left(\mathrm{K}^{+}\right)_{0}\right)$ and decreased extracellular calcium $\left(\left(\mathrm{Ca}^{2+}\right)_{0}\right)(89)$. These electrophysiological changes are associated with marked neuronal loss and reorganization of synaptic circuits in the hippocampus (96,108,111-113). The mechanisms underlying kainic acid-induced status epilepticus and subsequent epileptogenesis are considered to be mediated by selective activation of kainate receptors augmenting excitatory glutamatergic synapses in critical epileptogenic areas, such as the CA3 region of the hippocampus (114117).

In the last decades, the pilocarpine model has become the most popular and widely used rodent model of MTLE (118). This model has been developed by the administration of high doses of the cholinergic agonist pilocarpine $(320-400 \mathrm{mg} / \mathrm{kg})$ to rats and mice. Pilocarpine administration, at doses above $400 \mathrm{mg} / \mathrm{kg}$, resulted in a greater likelihood of induction of the complete syndrome and reduced latency to SE, but also increased mortality rate $(119,120)$. In addition, the pilocarpine model has been also proposed as a rodent model to mimic chemical warfare nerve agent exposure (121). A variant of the pilocarpine model consists in the induction of SE by the combination of lithium pre-treatment ( $\mathrm{LiCl}$, i.e., $3 \mathrm{mEq} / \mathrm{kg}$ ) followed 20 hours later by a small dose of pilocarpine $(25-30 \mathrm{mg} / \mathrm{kg})$ $(119,122-131)$ in adult rats. Subcutaneous administration of pilocarpine to rats that were pretreated with a small dose of lithium chloride results in the evolution of generalized convulsive status epilepticus (132). Interestingly, in contrast to rats, pretreatment with lithium does not potentiate the convulsant effect of pilocarpine in mice (133). Pre-treatment with lithium allows a significant reduction of the pilocarpine dose required to induce status epilepticus and results in a higher percentage of animals developing status epilepticus. Furthermore, a new variant of the model has been recently developed by intrahippocampal injection of pilocarpine $(134,135)$. In most of these variants of the pilocarpine model, a bloodbrain barrier non-permeable derivative of scopolamine (e.g. methyl-scopolamine, $1 \mathrm{mg} / \mathrm{kg}$ ) is administered 30 minutes prior to pilocarpine, to minimize systemic cholinergic side effects including excessive salivation, diarrhea, etc). The mechanisms by which pilocarpine induce status epilepticus are not completely clear, but it is thought that overstimulation of muscarinic receptors by pilocarpine triggering hippocampal hyper-synchronization and secondary activation of glutamatergic receptors lead to status epilepticus $(136,137)$. In the first minutes following pilocarpine injection, the animals experience head nodding, wet dog shakes, brief rearing consistent with activation of limbic pathways. These symptoms are followed by motor seizures (tonic clonic movements) lasting several seconds (usually less than $30 \mathrm{sec}$ ). After 2-3 of these seizures, animals enter in status epilepticus that can last several hours unless pharmacological intervention is performed. In most laboratories, convulsive behavior during status epilepticus is mitigated by diazepam (i.e., $10-20 \mathrm{mg} / \mathrm{kg}$ ) administered 2-4 hours after status epilepticus onset. This approach has been considered to improve mortality rate of the procedures (138-141). The duration of status epilepticus is critical for the development of the chronic phase. According to Lemos and Cavalheiro (1995), rats undergoing 30-min long SE and treated with a single (i.p.) injection of diazepam $(10 \mathrm{mg} / \mathrm{kg})$ and pentobarbital $(30$ $\mathrm{mg} / \mathrm{kg}$ ) do not develop spontaneous seizures (142). In contrast, animals presenting with SE lasting 1, 2, 6 or several hours exhibit latent periods of 52, 38, 17 and 14 days, respectively. However, it has also been reported that the latent period may be progressively shortened by decreasing the status epilepticus duration (143). Moreover, a recent study based on continuous video-EEG recordings revealed that the first spontaneous seizures occur 7.2+/-3.6 days after $2 \mathrm{~h}$ of pilocarpine-induced status epilepticus (144). These data indicate that epileptogenesis toward a chronic epileptic state may develop in a relatively short "latent" period following status epilepticus. Duration of 3 hours of the status epilepticus has been used in several studies to induce a chronic model with a relatively high frequency of recurrent spontaneous seizures when compared to a full-bloom non-interrupted status epilepticus (138-141). An advantage of limiting the duration to 3-4 hours is that status epilepticus-induced insult and consequent long-term modifications are similar across different animals in the same study, while status epilepticus of different durations may result in a wide range of cytoarchitectural and molecular abnormalities and probably very different seizure frequencies. Hence, data obtained from these animals will exhibit a large variability that may pose critical challenges for statistical analysis.

\subsubsection{In vivo epileptiform activity in hippocampus during pilocarpine-induced status epilepticus}

Previous studies using electroencephalographic recordings have reported that pilocarpine can evoke both ictal and interictal epileptic events. Low voltage, fast activity first appears in neocortex and amygdala, while a clear pattern of theta rhythm is evident in the hippocampus. When the behavioral manifestations become more severe, high voltage, fast EEG activity replaces the hippocampal theta rhythm (118,145-147). Moreover, at later stages, animals develop electrographic seizures, characterized by 

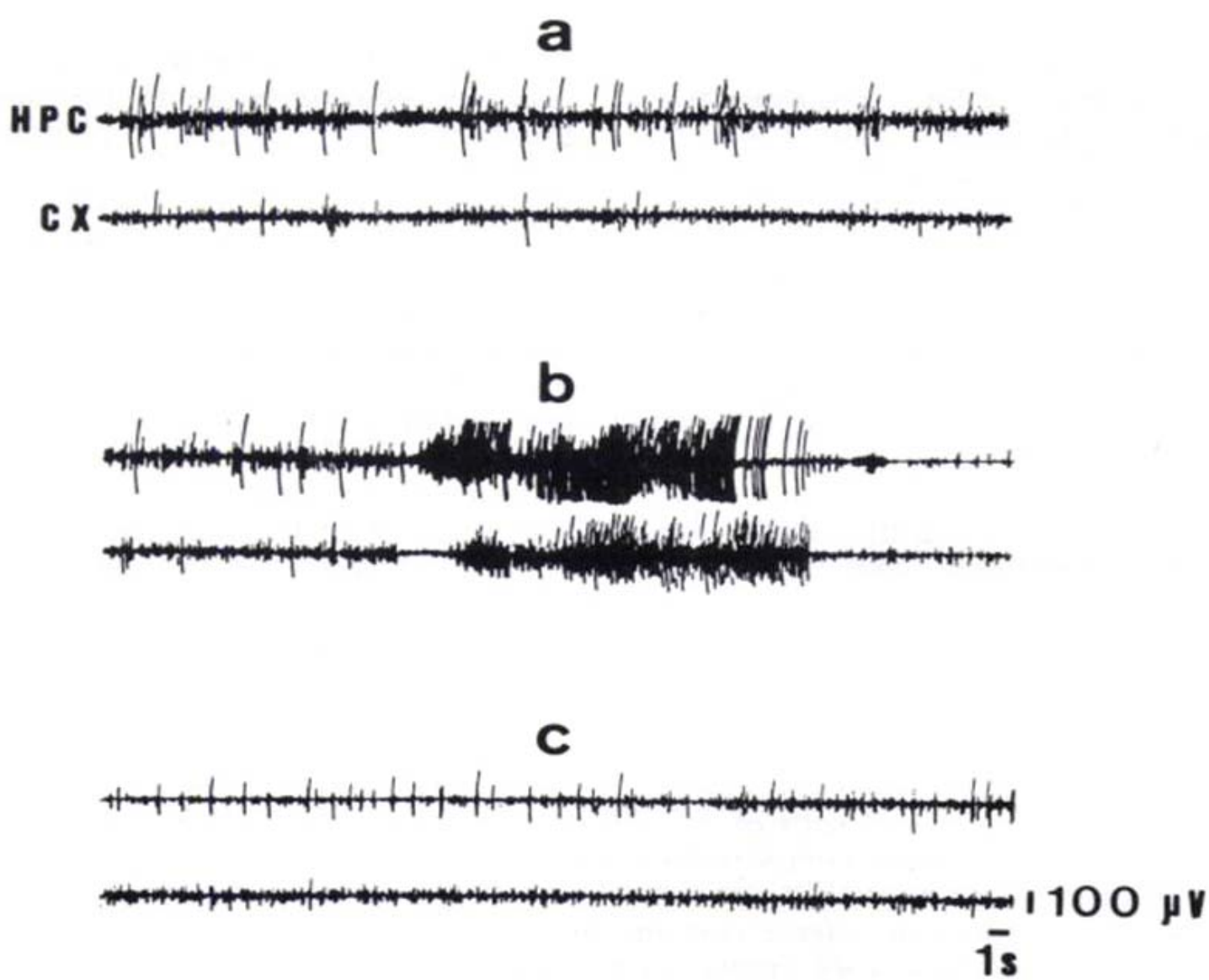

Figure 1. Electrographic recordings illustrating the buildup of a spontaneous recurrent seizure activity in a pilocarpine-treated chronically epileptic rat. The basal activity in the hippocampus (HPC) and cortex (CX) with isolated spikes is replaced by a burst of high voltage beginning in the HPC and spreading to CX. A, b, and c are continuous recordings. Figure adapted from Cavalheiro, 1995 (137)

high voltage, fast activity and prominent high voltage spiking that precedes seizures, most likely due to muscarinic system activation $(118,145)$.

\subsubsection{In vivo epileptiform activity during pilocarpine-} induced spontaneous recurrent seizures

EEG recordings performed during the chronic phase of the model revealed that spontaneous seizures in pilocarpine-treated animals are characterized by bursts of spiking activity in the hippocampus that spread to the neocortex in $90 \%$ of the cases (137) (Figure 1). According to that study, electrographic seizures rarely last more than $60 \mathrm{~s}$ and are followed by depressed background activity with frequent EEG interictal spikes. Bursts of spiking activity are not observed in the neocortex alone (148). In addition, interictal activity is more intense when animals are seizure-free and during the sleep period while they are almost undetectable during motor activity and paradoxical sleep (149).

3.3.3. In vitro epileptiform activity in slices obtained from pilocarpine-treated epileptic animals

Different modalities of electrophysiological recordings have demonstrated the presence of abnormal epileptiform activity in the limbic system of animal models of MTLE. In vitro electrophysiological studies on neurons and neuronal pathways of the limbic system have been developed using extracellular, intracellular and patch-clamp recordings in brain slices (hippocampal or entorhinalhippocampal preparations). These studies have demonstrated the presence of epileptiform electrographic abnormalities in almost all the areas of the limbic system. For instance, evoked and spontaneous epileptiform electrical activity has been reported in CA3, CA1, subiculum and dentate gyrus areas of the hippocampus.

In vitro hyperexcitability and epileptiform activity have been described in brain slices from different brain areas of chronically epileptic rats. The major feature of the epileptiform activity is a PDS of the membrane potential as recorded by intracellular sharp microelectrodes or whole-cell patch-clamp (current clamp in bridge-mode) configuration. Bursts of action potentials are associated with a network burst, which is the emergence poly-spiking activity in extracellular recordings from neighboring areas. The normal responses obtained by extracellular recordings (field potentials) with the electrode positioned in the stratum radiatum of CA3 area upon stratum lucidum 
Control

a

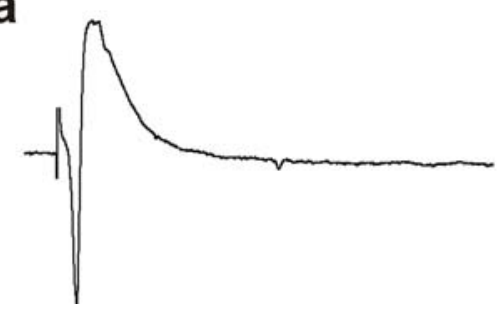

Epileptic

b

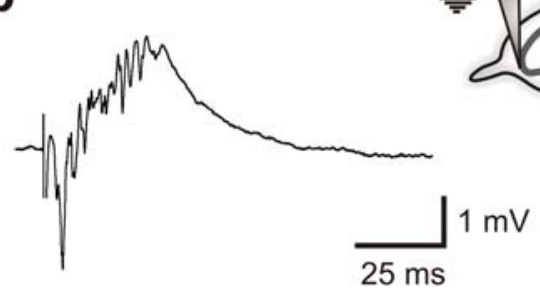

Figure 2. Hyper-responsiveness of hippocampal networks in hippocampal slices from pilocarpine-treated epileptic rats. A. In slices from saline-injected control rats, stimulation of mossy fiber pathway (i.e. bulk stimulation of hilar region) by a bipolar stimulator (i.e. $25 \mathrm{~V}$ ) elicits a single population spike (field potential) in the CA3 area recorded with a glass microelectrode pipette (extracellular recordings) filled with $1 \mathrm{mM} \mathrm{NaCl}$ and positioned in the external border of the pyramidal layer. B. In contrast, similar paradigm evoked a "burst" of several population spikes (poly-spiking "epileptiform" activity) in the same region of hippocampal slices obtained from pilocarpine-treated chronic epileptic rats sacrificed at 40 days following status epilepticus.

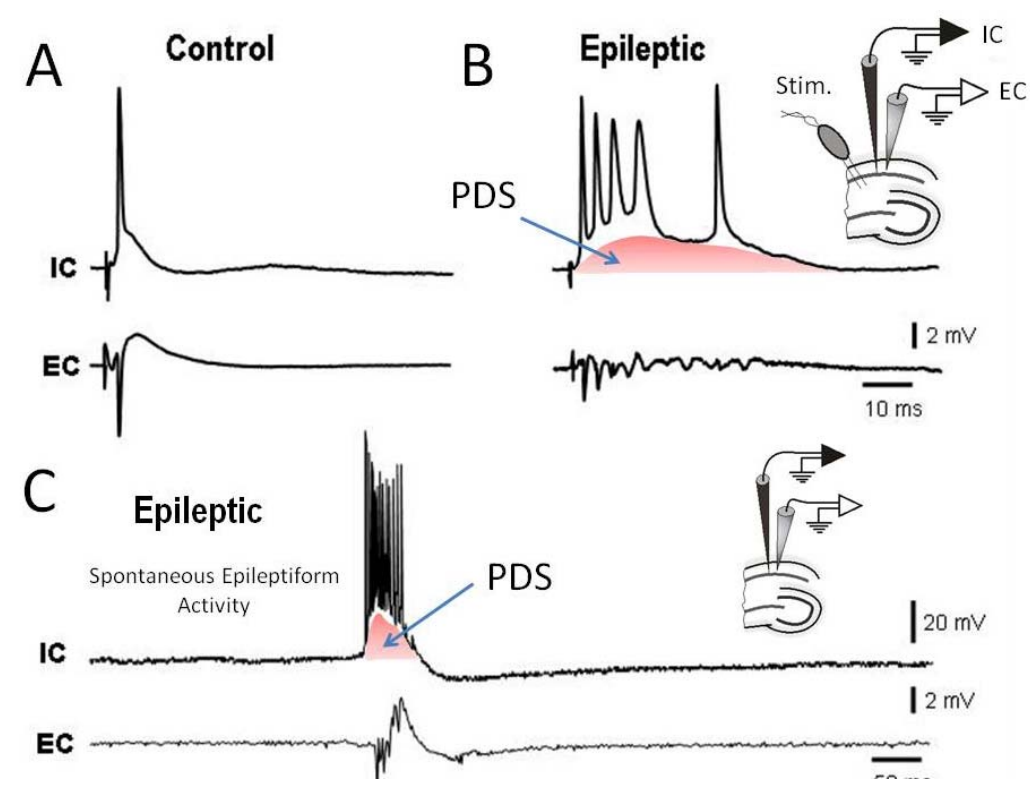

Figure 3. Epileptiform activity in the CA1 area of pilocarpine-treated epileptic rats. A. Supra-threshold stimulation of Schaffer collateral pathway trigger a single population spike recorded with extracellular (EC) electrodes positioned in the stratum pyramidale of CA1 area and a single action potential detected by intracellular (IC) electrode in pyramidal cell. In these experiments, the CA3 area was removed during slicing procedures. B. Under these conditions, similar paradigm evoked epileptiform (poly-spiking) activity in isolated CA1 area in slices from chronic epileptic rat. Notice that a in the intracellular recording, a burst of action potential emerge from a depolarizing wave (PDS) represented by the shadowed area. C. In this same recording configuration, spontaneous network epileptiform activity was detected in both electrodes indicating local hyperexcitability of CA1 area in epilepsy. Notice burst of action potentials during the PDS.

stimulation is characterized by a single population spike (Figure 2A). In contrast, a burst of multiple spikes (polyspiking activity) can be generated in the same area of hippocampal slices obtained from pilocarpine-treated epileptic rats (Figure 2B). In addition to this hyperresponsiveness, the amplitude of the responses evoked in the epileptic tissue is usually smaller when compared to control tissue $(138,150)$. It has been suggested that reduced amplitude results from extensive seizure-induced neuronal cell death in this area as a consequence of both the early epileptogenic insult (status epilepticus) and repetitive spontaneous seizures during the chronic phase of the model. Other studies have reported hyper-responsiveness of the area CA1 both in vivo and in vitro. For instance, spontaneous and evoked epileptiform activities characterized by brief events of multiple low-amplitude population spikes have been recorded in the CA1 area in slices where the area CA3 has been removed (150). Epileptiform activity in this area is characterized by burst of action potentials arising from an underlying PDS recorded by intracellular sharp electrodes in association with poly-spiking activity as recorded by extracellular recordings in pyramidal area (Figure 3), but hyperexcitability foci may emerge at different locations in 


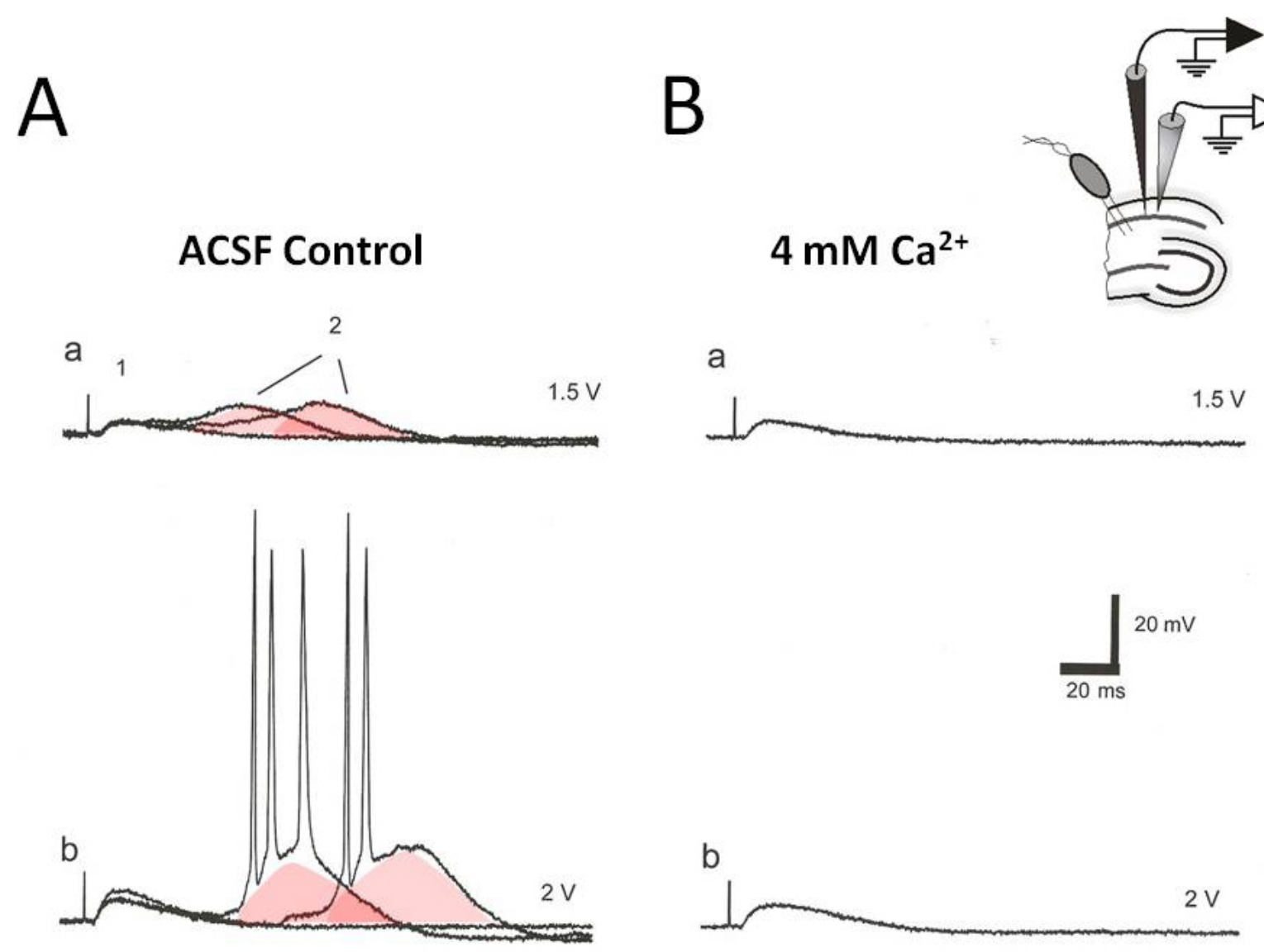

Figure 4. Abnormal excitatory connectivity in isolated CA1 area participates in the hyperexcitability observed during chronic epilepsy. A. A representative experiment in hippocampal CA1 micro-slice from chronic epileptic rat in standard ACSF (2 mM $\mathrm{Ca}^{2+}$ ) revealing that Schaffer collateral stimulation trigger an initial excitatory postsynaptic potential (EPSP) (1) at low stimulation intensity (1.5V) that is followed by a "rebound" EPSPs (2) eventually eliciting burst of action potentials ("epileptiform activity") riding depolarizing potentials (i.e. PDS) at higher stimulus intensity (2V) but still subthreshold for the first EPSP. B. Incubation of slices in ACSF containing higher concentration of divalent cations $\left(4 \mathrm{mM} \mathrm{Ca}^{2+}\right)$ abolished the "rebound" epileptiform EPSPs and the burst of action potential at same stimulation intensities as in A.

the limbic system of chronic epileptic rats. Compelling evidence indicates that the genesis of epileptiform discharges in CA1 area, and probably other limbic zones are mediated by different mechanisms including abnormal intrinsic properties of neurons (i.e., enhanced intrinsic bursting in the firing patterns, lack of accommodation), increased glutamatergic excitation due to abnormal NMDA and/or AMPA receptor function and expression, and reduced GABAergic inhibition (151-153). Sanabria et al, (2001) have proposed that activity of spontaneous "bursting" neurons in CA1 can synchronize and recruit the local neurons into a network burst (interictal like activity). However, spontaneous epileptiform activity is blocked by small concentration (i.e., $10 \mu \mathrm{M}$ ) of CNQX (150) or by an increase in divalent cation (i.e. $\left.\mathrm{Ca}^{2+}\right)$ concentrations in the artificial cerebrospinal fluid (ACSF) (Figure 4) suggesting that recurrent excitatory connections play an important role in the recruitment of neurons into epileptiform activity ("network burst"). In general, these findings are consistent with abnormalities of intrinsic properties and dysfunction of network connections and neurotransmission (excitatory and inhibitory) as has been classically proposed by the "epileptic neuron" and "epileptic aggregate" hypothesis to explain genesis of epileptic activity (154-157).

One of the distinctive features of the electrophysiology in MTLE is that responses evoked in the dentate gyrus following perforant path stimulation are, in most cases, not epileptiform. Cumulative evidence indicates that dentate gyrus functions as a filter that limits the propagation of epileptiform activity to limbic structures. Nonetheless, it is considered that during MTLE, this filter function is transiently altered prior to seizures. The mechanisms proposed for the transient disruption of dentate gyrus filter function are diverse. Dentate granule cells are characterized by low levels of excitability, an important aspect of hippocampal function, which distinguishes them from other principal cells of the hippocampus. For instance, recent studies indicate that, in contrast to pyramidal neurons, granule cells are intrinsically less excitable in the dentate gyrus of chronic epileptic rats and in human tissue removed during surgery for the treatment of drug-refractory 

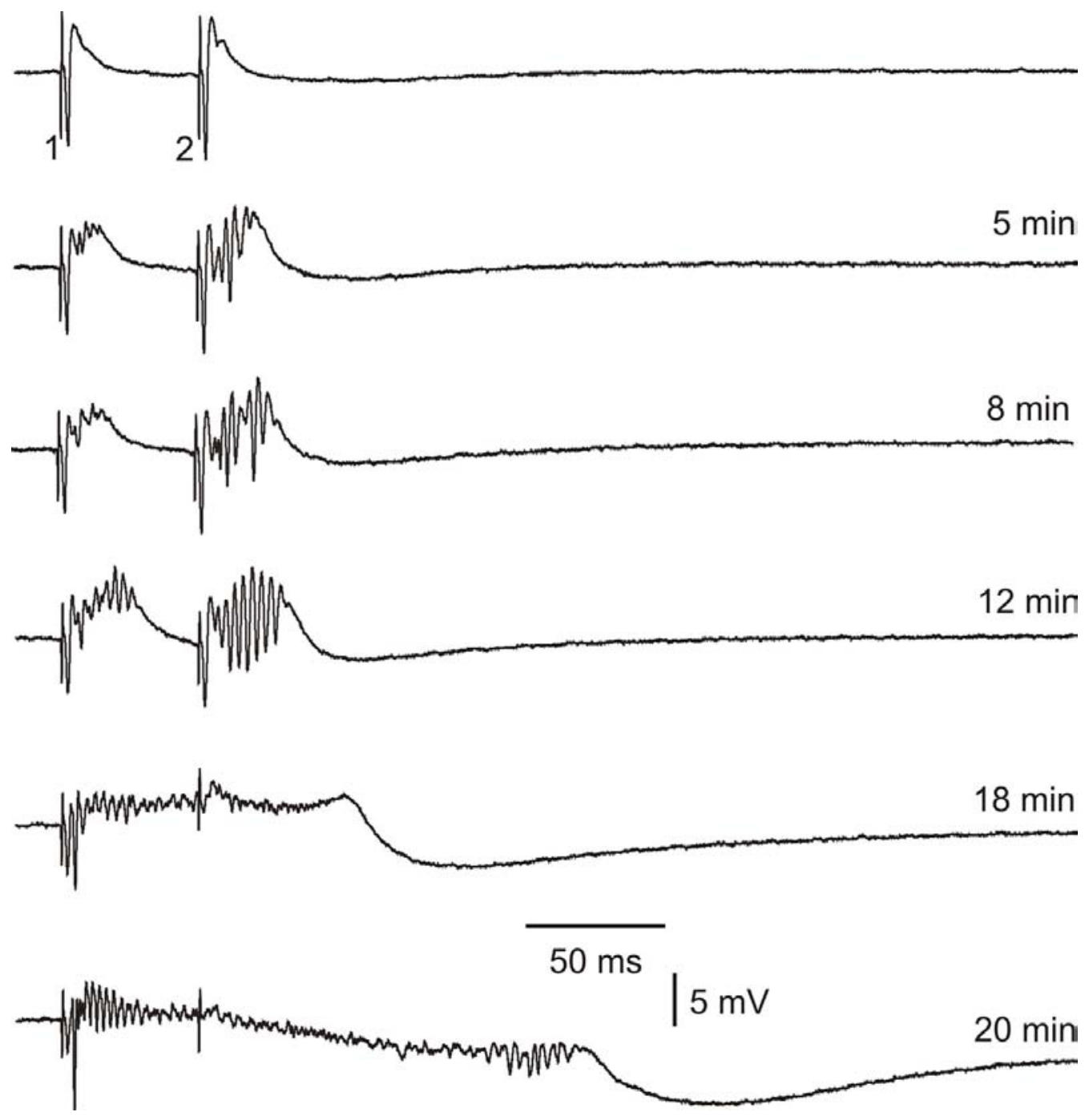

Figure 5. Epileptifom activity induced in hippocampal slice incubated in artificial cerebrospinal fluid containing $10 \mu \mathrm{M}$ of Bicuculline. Population spikes were recorded from the stratum pyramidale in CA3 area after paired stimulation of mossy fiber pathways (50 ms inter-stimulus interval, land 2, stimulus artifacts) using electrode positioned in the hilus of dentate gyrus. Notice the genesis and progressive nature of epileptiform activity over time after application of bicuculline characterized by increase in the number of population spikes and prolongation of the network burst.

epilepsy $(158,159)$. These findings play down the role of granule cell intrinsic excitability as one of the causes leading to disruption of dentate filter function. Moreover, it is widely accepted that network changes including transient disinhibition and excessive recurrent excitatory, mostly glutamatergic connectivity, play a pivotal role in the genesis and/or spreading of epileptiform activity through the dentate gyrus in MTLE (151). Supporting this notion, a large number of studies have reported an excess of glutamatergic recurrent excitation onto dendrites of granule cells as part of the active synaptic reorganization process associated with epileptogenesis (mossy fiber sprouting) (160-163). Interestingly, an increase in the GABAergic innervations has been also described in this area, although a recent electron microscopy and electrophysiological study indicates that the majority of the new connections are excitatory $(151,164-166)$.
3.3.4. In vitro models of acute epileptiform activy in limbic structures from normal animals

Several in vitro models have been developed to induce epileptiform activity in limbic areas from animals that are normal. Different types of convulsants (i.e., 4aminopyridine, bicuculline, pilocarpine, etc) can trigger electrical stimulus-evoked and spontaneous epileptiform activity in slices from hippocampus and other limbic structures (167-169) (170). The mechanims of these proconvulsive agents are quite different, for instance bicuculline blocks $\mathrm{GABA}_{\mathrm{A}}$ receptors inducing a disinhibition as a powerful stimulus to evoke an increase in excitability characterized by an increase in the number of population spikes and interictal like events (Figure 5). Changes in the ion concentration have been used as a manipulation to enhance excitability and induce in vitro 
Table 1. "In vitro" models of acute epileptiform activity in slices from control (no epileptic) rats

\begin{tabular}{|c|c|c|c|c|}
\hline Drugs and convulsants & Concentrations & Structure & Subfield & Reference \\
\hline Pilocarpine & $10 \mu \mathrm{M}$ & Hippocampus and entorhinal cortex & CA1-CA3 & $(170)$ \\
\hline 4-aminopyridine & $\begin{array}{l}50 \mu \mathrm{M} \\
100 \mu \mathrm{M}\end{array}$ & $\begin{array}{l}\text { Hippocampal } \\
\text { Ecthorinal cortex } \\
\text { hippocampus-entorhinal cortex }\end{array}$ & CA1-CA2-CA3 & $(167-169)$ \\
\hline Penicillin & $2 \mathrm{mM}$ & Hippocampal & CA1-CA3 & $(309)$ \\
\hline Bicuculline & $\begin{array}{l}10 \mu \mathrm{M} \\
20 \mu \mathrm{M} \\
100 \mu \mathrm{M}\end{array}$ & Hippocampal & CA2-CA3 & $(168)$ \\
\hline Veratridine & $0.3 \mu \mathrm{M}$ & Hippocampal & CA1 & $(310)$ \\
\hline Pentylenetetrazole & $? ? ?$ & Hippocampal & CA3 & (311) \\
\hline \multicolumn{5}{|l|}{ Ions } \\
\hline $\mathrm{Ca}^{2+}$ & $\begin{array}{l}\text { Low: less than or equal to } 0.2 \\
\mathrm{mM}\end{array}$ & Hippocampus & CA1 & $(312,313)$ \\
\hline $\mathrm{Mg}^{2+}$ & $\begin{array}{l}{ }^{+} \text {free } \\
\text { Low } \\
\text { high }\end{array}$ & $\begin{array}{l}\text { Primary hippocampal cultures } \\
\text { Organotypic cultured } \\
\text { Organotypic cultures } \\
\text { Amygdala }\end{array}$ & Different areas & $\begin{array}{l}(176,314- \\
317) \\
(318)\end{array}$ \\
\hline $\mathrm{K}^{+}$ & 3 to $10 \mathrm{mM}$ & Parahippocampal & CA1-CA3 & $(319,320)$ \\
\hline Organophosphate anticholinesterase soman & $100 \mathrm{nM}$ & Hippocampus & & $(321,322)$ \\
\hline \multicolumn{5}{|l|}{ Electrical } \\
\hline Tetanic-like stimulation & $\begin{array}{l}100 \mathrm{~Hz} .2 \mathrm{~s} \text { in duration, once } \\
\text { every } 10 \mathrm{~min}, 10 \text { episodes }\end{array}$ & $\begin{array}{l}\text { Piriform-cortex } \\
\text { hippocampal- parahippocampal }\end{array}$ & & (323) \\
\hline Train of pulses & $60 \mathrm{~Hz}$, pulse duration $100 \mathrm{us}$ & Hippocampal & CA3 & $(169,324)$ \\
\hline
\end{tabular}

epileptiform activity. Among these modifications, increasing the concentration of potassium can enhance neuronal excitability. Pro-epileptic action of potassium increase is thought to be mediated by different mechanisms including increasing the number of intrinsically bursting neurons $(171,172)$, reducing the driving force of potassium, reduction of $\mathrm{GABA}_{\mathrm{A}}$-mediated inhibition (173), swelling of neurons and increase in nonsynaptic interactions (174). In addition, low calcium and low magnesium can induce seizure-like events in the hippocampus (175-177). Although the mechanisms underlying the low-calcium induction of epileptiform activity are unknow, it has been demonstrated that removal of magnesium enhances $\mathrm{N}$ methyl-D-Aspartate (NMDA) receptor-mediated currents $(178,179)$ triggering an increase in glutamatergic excitation. The free-magnesium model of in vitro seizure activity in hippocampus has been used to evaluate the action of different anticonvulsant agents (180). Electrical stimulation (tetanus-like paradigms) has been also utilized to evoke in vitro epileptiform activity in limbic areas (Table 1). Acute models of in vitro epileptiform activity, especially in hippocampal slices, have been useful for screening potentially anticonvulsant compounds and in studying the mechanisms and pharmacology of epileptic activity (181-187). However, their predictive value for discovering new therapeutic drugs for epilepsy is hindered by the fact that ion channels, receptors and other molecular mechanisms in normal tissue are different than the ones expressed in chronically epileptic tissue.

\section{GENETIC VERSUS ACQUIRED CHANNELOPATHIES}

Channelopathies are diseases caused by impaired function of ion channel subunits or proteins which regulate them $(188,189)$. These diseases may be either congenital (often resulting from a mutation or mutations in the encoding genes) or acquired (often resulting from autoimmune attack on an ion channel) $(188,189)$.
Ion channel mutations have been causally implicated in a number of distinct disorders $(188,189)$. For instance, congenital hyperinsulinism is caused by a mutation which results in deficiency in the expression of the inward-rectifying potassium channel subunit $\mathrm{K}_{\mathrm{IR}} 6.2$ (190). In addition, most forms of myasthenia gravis, a neuromuscular disease leading to fluctuating muscle weakness and fatigability is a kind of acquired channelopathy caused by the production of antibodies directed against nicotinic acetylcholine receptors at the neuromuscular junction (191). Moreover, every human epilepsy syndrome for which a gene mutation has been identified is associated with dysfunction in ion channel subunits (192), characterizing inherited epilepsy as a genetic channelopathy. For instance, a mutation in the gene for $\mathrm{K}_{\mathrm{V}} 7.2$ channel subunit causes the type 1 benign neonatal epilepsy (193), whereas mutation in the gene responsible for the alpha $\mathrm{H}_{\mathrm{H}}$ channel subunit $\left(\mathrm{Ca}_{\mathrm{V}} 3.2\right)$ causes type 1 childhood absence epilepsy (194). In addition, sodium channel mutations that are associated with increased $\mathrm{Na}_{\mathrm{V}}$ activity (e.g. $\mathrm{Na}_{\mathrm{V}} 1.1$ channel subunit) can lead to enhanced seizure susceptibility, as in the severe myoclonic epilepsy of infancy GEFS+ type 2 (195-198).

In addition, ion channelopathy has been similarly hypothesized to play a role in acquired epilepsy due to central nervous system insult, such as status epilepticus. In this context, MTLE has been considered as a complex form of acquired channelopathy $(12,199-204)$. While one may promptly figure out altered gene expression as a cause for acquired channelopathies, alternative splicing, altered protein processing, trafficking and recycling and posttranslational modifications, such as protein phosphorylation may also contribute to an acquired ion channel dysfunction.

\section{MTLE AS AN ACQUIRED CHANNELOPATHY}

At a microscopy level, seizures and status epilepticus are known to produce multiple morphological abnormalities in the limbic system (i.e. loss of principal 
Table 2. Alterations in mRNA and protein levels of voltage-gated channels in MTLE

\begin{tabular}{|c|c|c|c|c|c|c|}
\hline Channel family & $\begin{array}{l}\text { Receptor } \\
\text { (Common name/IUPHAR } \\
\text { name/Gene name) }\end{array}$ & Model & Site & mRNA & Protein & Reference \\
\hline $\begin{array}{ll}\text { Ca2+-Activated } & \mathrm{K}+ \\
\text { Channels }\end{array}$ & $\mathrm{BK} / \mathrm{KCa} 1.1 / \mathrm{Kcnma} 1$ & Pilocarpine & Rat DG & $\downarrow$ & NA & (139) \\
\hline $\begin{array}{ll}\text { Ca2+-Activated } & \mathrm{K}+ \\
\text { Channels } & \\
\end{array}$ & BK/KCa1.1/Kcnma1 & Pilocarpine & Rat CA3 & $\downarrow$ & $\downarrow$ & (268) \\
\hline $\begin{array}{ll}\text { Cyclic } & \text { Nucleotide- } \\
\text { Regulated Channels }\end{array}$ & $\mathrm{HCN} 1 / \mathrm{HCN} 1 / \mathrm{HCN} 1$ & Pilocarpine & Rat CA1 & NA & $\downarrow$ & (199) \\
\hline $\begin{array}{l}\text { Cyclic Nucleotide- } \\
\text { Regulated Channels }\end{array}$ & $\mathrm{HCN} 1 / \mathrm{HCN} 1 / \mathrm{HCN} 1$ & Pilocarpine & Rat CA1 & $\downarrow$ & NA & (204) \\
\hline $\begin{array}{l}\text { Cyclic Nucleotide- } \\
\text { Regulated Channels }\end{array}$ & $\mathrm{HCN} 1 / \mathrm{HCN} 1 / \mathrm{HCN} 1$ & Pilocarpine & Rat DG & $\uparrow$ & $\uparrow$ & (294) \\
\hline $\begin{array}{l}\text { Cyclic Nucleotide- } \\
\text { Regulated Channels }\end{array}$ & $\mathrm{HCN} 1 / \mathrm{HCN} 1 / \mathrm{HCN} 1$ & $\begin{array}{l}\text { Human temporal } \\
\text { lobe epilepsy }\end{array}$ & Human DG & $\uparrow$ & $\uparrow$ & (294) \\
\hline $\begin{array}{ll}\text { Cyclic Nucleotide- } \\
\text { Regulated Channels }\end{array}$ & $\mathrm{HCN} 1 / \mathrm{HCN} 1 / \mathrm{HCN} 1$ & Kainate & Rat CA1 & NA & $\downarrow$ & (303) \\
\hline $\begin{array}{l}\text { Cyclic Nucleotide- } \\
\text { Regulated Channels }\end{array}$ & $\mathrm{HCN} 1 / \mathrm{HCN} 1 / \mathrm{HCN} 1$ & Kainate & Rat CA1 & $\downarrow$ & NA & (295) \\
\hline $\begin{array}{l}\text { Cyclic Nucleotide- } \\
\text { Regulated Channels }\end{array}$ & HCN1/HCN1/HCN1 & Kainate & Rat DG & $\leftrightarrow$ & NA & (295) \\
\hline $\begin{array}{ll}\text { Cyclic } & \text { Nucleotide- } \\
\text { Regulated Channels }\end{array}$ & $\mathrm{HCN} 1 / \mathrm{HCN} 1 / \mathrm{HCN} 1$ & $\begin{array}{l}\text { Amygdala } \\
\text { kindling } \\
\end{array}$ & Rat CA1 & $\leftrightarrow$ & NA & (295) \\
\hline $\begin{array}{l}\text { Cyclic Nucleotide- } \\
\text { Regulated Channels }\end{array}$ & HCN1/HCN1/HCN1 & $\begin{array}{l}\text { Amygdala } \\
\text { kindling }\end{array}$ & Rat DG & $\leftrightarrow$ & NA & (295) \\
\hline $\begin{array}{ll}\text { Cyclic Nucleotide- } \\
\text { Regulated Channels }\end{array}$ & $\mathrm{HCN} 2 / \mathrm{HCN} 2 / \mathrm{HCN} 2$ & Pilocarpine & Rat CA1 & NA & $\leftrightarrow$ & (199) \\
\hline $\begin{array}{ll}\text { Cyclic Nucleotide- } \\
\text { Regulated Channels }\end{array}$ & $\mathrm{HCN} 2 / \mathrm{HCN} 2 / \mathrm{HCN} 2$ & Pilocarpine & Rat CA1 & $\downarrow$ & NA & (204) \\
\hline $\begin{array}{ll}\text { Cyclic Nucleotide- } \\
\text { Regulated Channels }\end{array}$ & $\mathrm{HCN} 2 / \mathrm{HCN} 2 / \mathrm{HCN} 2$ & Pilocarpine & Rat DG & $\leftrightarrow$ & $\leftrightarrow$ & (294) \\
\hline $\begin{array}{ll}\text { Cyclic Nucleotide- } & \text { Nucts } \\
\text { Regulated Channels }\end{array}$ & $\mathrm{HCN} 2 / \mathrm{HCN} 2 / \mathrm{HCN} 2$ & $\begin{array}{l}\text { Human temporal } \\
\text { lobe epilepsy }\end{array}$ & Human DG & $\leftrightarrow$ & $\leftrightarrow$ & (294) \\
\hline $\begin{array}{ll}\text { Cyclic Nucleotide- } \\
\text { Regulated Channels }\end{array}$ & $\mathrm{HCN} 2 / \mathrm{HCN} 2 / \mathrm{HCN} 2$ & Kainate & Rat CA1 & NA & $\downarrow$ & (303) \\
\hline $\begin{array}{l}\text { Cyclic Nucleotide- } \\
\text { Regulated Channels }\end{array}$ & $\mathrm{HCN} 2 / \mathrm{HCN} 2 / \mathrm{HCN} 2$ & Kainate & Rat CA1 & $\downarrow$ & NA & (295) \\
\hline $\begin{array}{l}\text { Cyclic Nucleotide- } \\
\text { Regulated Channels }\end{array}$ & $\mathrm{HCN} 2 / \mathrm{HCN} 2 / \mathrm{HCN} 2$ & Kainate & Rat DG & $\downarrow$ & NA & (295) \\
\hline $\begin{array}{l}\text { Cyclic Nucleotide- } \\
\text { Regulated Channels }\end{array}$ & $\mathrm{HCN} 2 / \mathrm{HCN} 2 / \mathrm{HCN} 2$ & $\begin{array}{l}\text { Amygdala } \\
\text { kindling }\end{array}$ & Rat CA1 & $\leftrightarrow$ & NA & (295) \\
\hline $\begin{array}{l}\text { Cyclic Nucleotide- } \\
\text { Regulated Channels }\end{array}$ & $\mathrm{HCN} 2 / \mathrm{HCN} 2 / \mathrm{HCN} 2$ & $\begin{array}{l}\text { Amygdala } \\
\text { kindling }\end{array}$ & Rat DG & $\leftrightarrow$ & NA & (295) \\
\hline $\begin{array}{l}\text { Inwardly Rectifying } \mathrm{K}+ \\
\text { Channels }\end{array}$ & GIRK2/Kir3.2/KCNJ6 & Kainate & Rat DG & $\uparrow$ & $\uparrow$ & (274) \\
\hline $\begin{array}{l}\text { Inwardly Rectifying } \mathrm{K}+ \\
\text { Channels }\end{array}$ & GIRK2/Kir3.2/KCNJ6 & Kainate & Rat CA1, CA3 & $\leftrightarrow$ & $\leftrightarrow$ & (274) \\
\hline $\begin{array}{l}\text { Inwardly Rectifying } \mathrm{K}+ \\
\text { Channels }\end{array}$ & IRK1/Kir2.1/KCNJ2 & Kainate & Mouse DG & NA & $\uparrow$ & (158) \\
\hline $\begin{array}{l}\text { Inwardly Rectifying K+ } \\
\text { Channels }\end{array}$ & IRK2/Kir2.2/KCNJ12 & Kainate & Mouse DG & NA & $\uparrow$ & (158) \\
\hline $\begin{array}{l}\text { Inwardly Rectifying } \mathrm{K}+ \\
\text { Channels }\end{array}$ & IRK3/Kir2.3/KCNJ4 & Kainate & Mouse DG & NA & $\uparrow$ & (158) \\
\hline $\begin{array}{l}\text { Inwardly Rectifying } \mathrm{K}+ \\
\text { Channels }\end{array}$ & IRK3/Kir2.3/KCNJ4 & Pilocarpine & $\begin{array}{l}\text { Rat } \\
\text { hippocampus } \\
\end{array}$ & $\downarrow$ & NA & (271) \\
\hline $\begin{array}{l}\text { Inwardly Rectifying } \mathrm{K}+ \\
\text { Channels }\end{array}$ & IRK3/Kir2.3/KCNJ4 & $\begin{array}{l}\text { Human temporal } \\
\text { lobe epilepsy }\end{array}$ & $\begin{array}{l}\text { Human temporal } \\
\text { cortex }\end{array}$ & $\downarrow$ & $\downarrow$ & $(270)$ \\
\hline $\begin{array}{l}\text { Inwardly Rectifying } \mathrm{K}+ \\
\text { Channels }\end{array}$ & IRK4/Kir2.4/KCNJ14 & Kainate & Mouse DG & NA & $\uparrow$ & (158) \\
\hline $\begin{array}{lr}\text { Two-pore } & \text { Weak } \\
\text { Inwardly Rectifying K+ } \\
\text { Channels }\end{array}$ & Twik1/K2P1.1/KCNK1 & Kainate & Mouse DG & NA & $\uparrow$ & (158) \\
\hline $\begin{array}{lr}\text { Two-pore } & \text { Weak } \\
\text { Inwardly Rectifying K }+ \\
\text { Channels }\end{array}$ & Twik2/K2P6.1/KCNK6 & Kainate & Mouse DG & NA & $\uparrow$ & (158) \\
\hline $\begin{array}{lr}\text { Two-pore } & \text { Weak } \\
\text { Inwardly Rectifying K+ } \\
\text { Channels }\end{array}$ & TASK-1/K2P3.1/KCNK3 & Pilocarpine & Rat DG & NA & $\downarrow$ & $(272)$ \\
\hline $\begin{array}{lr}\text { Two-pore } & \text { Weak } \\
\text { Inwardly Rectifying K+ } \\
\text { Channels }\end{array}$ & TASK-1/K2P3.1/KCNK3 & Pilocarpine & Rat CA1 & NA & $\leftrightarrow$ & $(272)$ \\
\hline $\begin{array}{lr}\text { Two-pore } & \text { Weak } \\
\text { Inwardly Rectifying K+ } \\
\text { Channels }\end{array}$ & TASK-2/K2P5.1/KCNK5 & Pilocarpine & Rat DG & NA & $\uparrow$ & (273) \\
\hline $\begin{array}{ll}\text { Two-pore } & \text { Weak } \\
\end{array}$ & TASK-2/K2P5.1/KCNK5 & Pilocarpine & Rat CA1 & NA & $\downarrow$ & (273) \\
\hline
\end{tabular}




\begin{tabular}{|c|c|c|c|c|c|c|}
\hline $\begin{array}{l}\text { Inwardly Rectifying } \mathrm{K}+ \\
\text { Channels }\end{array}$ & & & & & & \\
\hline $\begin{array}{l}\text { Two-pore Weak } \\
\text { Inwardly Rectifying K+ } \\
\text { Channels }\end{array}$ & TASK-2/K2P5.1/KCNK5 & Pilocarpine & Rat CA3 & NA & $\uparrow$ & (273) \\
\hline $\begin{array}{ll}\text { Voltage-Gated } & \mathrm{Ca} 2+ \\
\text { Channels } & \\
\end{array}$ & $\begin{array}{ll}\text { T-type } & (\alpha 1 \mathrm{G}) / \mathrm{CaV} 3.1 / \\
\text { CACNA1G } & \\
\end{array}$ & Pilocarpine & Rat CA1 & $\leftrightarrow$ & $\leftrightarrow$ & (289) \\
\hline $\begin{array}{ll}\text { Voltage-Gated } & \mathrm{Ca} 2+ \\
\text { Channels } & \end{array}$ & $\begin{array}{ll}\text { T-type } & (\alpha 1 \mathrm{H}) / \mathrm{CaV} 3.2 / \\
\text { CACNA1H } & \end{array}$ & Pilocarpine & Rat CA1 & $\uparrow$ & $\uparrow$ & (289) \\
\hline $\begin{array}{l}\text { Voltage-Gated } \\
\text { Channels }\end{array}$ & $\begin{array}{l}\text { T-type } \quad(\alpha 1 \mathrm{I}) / \mathrm{CaV} 3.3 / \\
\text { CACNA1I }\end{array}$ & Pilocarpine & Rat CA1 & $\leftrightarrow$ & $\leftrightarrow$ & $(289)$ \\
\hline $\begin{array}{ll}\text { Voltage-Gated } & \mathrm{Ca} 2+ \\
\text { Channels } & \end{array}$ & $\begin{array}{ll}\text { L-type } & (\alpha 1 \mathrm{C}) / \mathrm{CaV} 1.2 / \\
\text { CACNA1C } & \end{array}$ & Pilocarpine & $\begin{array}{l}\text { Rat } \\
\text { hippocampus }\end{array}$ & $\uparrow$ & $\uparrow$ & (290) \\
\hline $\begin{array}{ll}\text { Voltage-Gated } & \mathrm{Ca} 2+ \\
\text { Channels } & \\
\end{array}$ & $\begin{array}{ll}\text { L-type } & (\alpha 1 \mathrm{C}) / \mathrm{CaV} 1.2 / \\
\text { CACNA1C } & \\
\end{array}$ & $\begin{array}{l}\text { Human temporal } \\
\text { lobe epilepsy }\end{array}$ & Human DG & NA & $\downarrow$ & $(292)$ \\
\hline $\begin{array}{ll}\text { Voltage-Gated } & \mathrm{Ca} 2+ \\
\text { Channels } & \\
\end{array}$ & $\begin{array}{ll}\text { L-type } & (\alpha 1 \mathrm{D}) / \mathrm{CaV} 1.3 / \\
\text { CACNA1D } & \\
\end{array}$ & $\begin{array}{l}\text { Human temporal } \\
\text { lobe epilepsy }\end{array}$ & Human DG & NA & $\uparrow$ & (292) \\
\hline $\begin{array}{l}\text { Voltage-Gated } \\
\text { Channels }\end{array}$ & $\begin{array}{ll}\text { L-type } & (\alpha 1 \mathrm{D}) / \mathrm{CaV} 1.3 / \\
\text { CACNA1D } & \end{array}$ & Pilocarpine & $\begin{array}{l}\text { Rat } \\
\text { hippocampus }\end{array}$ & $\uparrow$ & $\uparrow$ & $(290)$ \\
\hline $\begin{array}{ll}\text { Voltage-Gated } & \mathrm{Ca} 2+ \\
\text { Channels } & \\
\end{array}$ & $\begin{array}{ll}\text { P/Q-type } & (\alpha 1 \mathrm{~A}) / \mathrm{CaV} 2.1 / \\
\text { CACNA1A } & \end{array}$ & Pilocarpine & $\begin{array}{l}\text { Rat } \\
\text { hippocampus }\end{array}$ & $\uparrow$ & $\uparrow$ & $(290)$ \\
\hline $\begin{array}{ll}\text { Voltage-Gated } & \mathrm{Ca} 2+ \\
\text { Channels } & \\
\end{array}$ & $\begin{array}{ll}\text { P/Q-type } & (\alpha 1 \mathrm{~A}) / \mathrm{CaV} 2.1 / \\
\text { CACNA1A } & \end{array}$ & Kainate & Rat DG & $\uparrow$ & NA & (291) \\
\hline $\begin{array}{l}\text { Voltage-Gated } \mathrm{Ca} 2+ \\
\text { Channels }\end{array}$ & $\begin{array}{ll}\text { P/Q-type } & (\alpha 1 \mathrm{~A}) / \mathrm{CaV} 2.1 / \\
\text { CACNA1A }\end{array}$ & $\begin{array}{l}\text { Human temporal } \\
\text { lobe epilepsy }\end{array}$ & $\begin{array}{l}\text { Human DG, } \\
\text { CA3 }\end{array}$ & NA & $\uparrow$ & $(292)$ \\
\hline $\begin{array}{l}\text { Voltage-Gated } \mathrm{Ca} 2+ \\
\text { Channels }\end{array}$ & $\begin{array}{l}\text { N-type } \\
\text { CACNA1B }\end{array}$ & $\begin{array}{l}\text { Human temporal } \\
\text { lobe epilepsy }\end{array}$ & Human DG & NA & $\uparrow$ & (292) \\
\hline $\begin{array}{ll}\text { Voltage-Gated } & \mathrm{Ca} 2+ \\
\text { Channels } & \end{array}$ & $\begin{array}{ll}\text { R-type } & (\alpha 1 \mathrm{E}) / \mathrm{CaV} 2.2 / \\
\text { CACNA1B }\end{array}$ & $\begin{array}{l}\text { Human temporal } \\
\text { lobe epilepsy }\end{array}$ & Human DG & NA & $\uparrow$ & (292) \\
\hline $\begin{array}{l}\text { Voltage-Gated } \\
\text { Channels }\end{array}$ & $\beta 1 / \mathrm{CACNB} 1$ & $\begin{array}{l}\text { Human temporal } \\
\text { lobe epilepsy }\end{array}$ & Human CA & NA & $\uparrow$ & (293) \\
\hline $\begin{array}{ll}\text { Voltage-Gated } & \mathrm{Ca} 2+ \\
\text { Channels } & \\
\end{array}$ & $\beta 2 / \mathrm{CACNB} 2$ & $\begin{array}{l}\text { Human temporal } \\
\text { lobe epilepsy }\end{array}$ & Human CA & NA & $\uparrow$ & (293) \\
\hline $\begin{array}{ll}\text { Voltage-Gated } & \mathrm{Ca} 2+ \\
\text { Channels } & \end{array}$ & $\beta 3 / \mathrm{CACNB} 3$ & $\begin{array}{l}\text { Human temporal } \\
\text { lobe epilepsy }\end{array}$ & Human CA & NA & $\leftrightarrow$ & (293) \\
\hline $\begin{array}{l}\text { Voltage-Gated } \mathrm{Ca} 2+ \\
\text { Channels }\end{array}$ & $\beta 4 / \mathrm{CACNB} 4$ & $\begin{array}{l}\text { Human temporal } \\
\text { lobe epilepsy }\end{array}$ & Human CA & NA & $\leftrightarrow$ & (293) \\
\hline $\begin{array}{ll}\text { Voltage-Gated } & \mathrm{Na}+ \\
\text { Channels } & \\
\end{array}$ & NaV1.1/SCN1A & $\begin{array}{l}\text { Human temporal } \\
\text { lobe epilepsy }\end{array}$ & $\begin{array}{l}\text { Human } \\
\text { hippocampus }\end{array}$ & See legend & NA & (325) \\
\hline $\begin{array}{ll}\text { Voltage-Gated } & \mathrm{Na}+ \\
\text { Channels } & \\
\end{array}$ & NaV1.1/SCN1A & $\begin{array}{l}\text { Human temporal } \\
\text { lobe epilepsy }\end{array}$ & $\begin{array}{l}\text { Human } \\
\text { hippocampus }\end{array}$ & $\leftrightarrow$ & NA & (278) \\
\hline $\begin{array}{ll}\text { Voltage-Gated } & \mathrm{Na}+ \\
\text { Channels } & \\
\end{array}$ & NaV1.1/SCN1A & Pilocarpine & Rat DG & $\leftrightarrow$ & NA & (200) \\
\hline $\begin{array}{ll}\text { Voltage-Gated } & \mathrm{Na}+ \\
\text { Channels } & \end{array}$ & NaV1.1/SCN1A & Pilocarpine & Rat CA1 & $\leftrightarrow$ & $\leftrightarrow$ & (279) \\
\hline $\begin{array}{l}\text { Voltage-Gated } \mathrm{Na}+ \\
\text { Channels }\end{array}$ & $\mathrm{NaV} 1.2 / \mathrm{SCN} 2 \mathrm{~A}$ & $\begin{array}{l}\text { Human temporal } \\
\text { lobe epilepsy }\end{array}$ & $\begin{array}{l}\text { Human } \\
\text { hippocampus }\end{array}$ & See legend & NA & (325) \\
\hline $\begin{array}{ll}\text { Voltage-Gated } & \mathrm{Na}+ \\
\text { Channels } & \\
\end{array}$ & $\mathrm{NaV} 1.2 / \mathrm{SCN} 2 \mathrm{~A}$ & $\begin{array}{l}\text { Human temporal } \\
\text { lobe epilepsy }\end{array}$ & $\begin{array}{l}\text { Human } \\
\text { hippocampus }\end{array}$ & $\downarrow$ & NA & (278) \\
\hline $\begin{array}{ll}\text { Voltage-Gated } & \mathrm{Na}+ \\
\text { Channels } & \\
\end{array}$ & $\mathrm{NaV} 1.2 / \mathrm{SCN} 2 \mathrm{~A}$ & Pilocarpine & Rat DG & $\downarrow$ & NA & (200) \\
\hline $\begin{array}{ll}\text { Voltage-Gated } & \mathrm{Na}+ \\
\text { Channels } & \\
\end{array}$ & $\mathrm{NaV} 1.3 / \mathrm{SCN} 3 \mathrm{~A}$ & $\begin{array}{l}\text { Human temporal } \\
\text { lobe epilepsy }\end{array}$ & $\begin{array}{l}\text { Human } \\
\text { hippocampus }\end{array}$ & $\uparrow$ & NA & (278) \\
\hline $\begin{array}{ll}\text { Voltage-Gated } & \mathrm{Na}+ \\
\text { Channels } & \\
\end{array}$ & $\mathrm{NaV} 1.3 / \mathrm{SCN} 3 \mathrm{~A}$ & Pilocarpine & Rat DG & $\leftrightarrow$ & NA & (200) \\
\hline $\begin{array}{ll}\text { Voltage-Gated } & \mathrm{Na}+ \\
\text { Channels } & \end{array}$ & NaV1.4/SCN4A & $\begin{array}{l}\text { Human temporal } \\
\text { lobe epilepsy }\end{array}$ & $\begin{array}{l}\text { Human } \\
\text { hippocampus }\end{array}$ & $\leftrightarrow$ & NA & (278) \\
\hline $\begin{array}{ll}\text { Voltage-Gated } & \mathrm{Na}+ \\
\text { Channels } & \\
\end{array}$ & $\mathrm{NaV} 1.5 / \mathrm{SCN} 5 \mathrm{~A}$ & Pilocarpine & Rat DG & $\leftrightarrow$ & NA & (200) \\
\hline $\begin{array}{ll}\text { Voltage-Gated } & \mathrm{Na}+ \\
\text { Channels } & \\
\end{array}$ & NaV1.6/SCN8A & Pilocarpine & Rat DG & $\downarrow$ & NA & (200) \\
\hline $\begin{array}{l}\text { Voltage-Gated } \mathrm{Na}+ \\
\text { Channels }\end{array}$ & NaV1.6/SCN8A & Pilocarpine & Rat CA1 & $\uparrow$ & $\uparrow$ & (279) \\
\hline $\begin{array}{ll}\text { Voltage-Gated } & \mathrm{Na}+ \\
\text { Channels } & \end{array}$ & $\mathrm{NaV} \beta 1 / \mathrm{SCN} 1 \mathrm{~B}$ & $\begin{array}{l}\text { Human temporal } \\
\text { lobe epilepsy }\end{array}$ & $\begin{array}{l}\text { Human } \\
\text { hippocampus }\end{array}$ & NA & $\uparrow$ & (281) \\
\hline $\begin{array}{ll}\text { Voltage-Gated } & \mathrm{Na}+ \\
\text { Channels } & \\
\end{array}$ & NaV $\beta 1 / S C N 1 B$ & Pilocarpine & Rat DG & $\downarrow$ & NA & (200) \\
\hline $\begin{array}{ll}\text { Voltage-Gated } & \mathrm{Na}+ \\
\text { Channels } & \\
\end{array}$ & $\mathrm{NaV} \beta 2 / \mathrm{SCN} 2 \mathrm{~B}$ & Pilocarpine & Rat DG & $\leftrightarrow$ & NA & (200) \\
\hline $\begin{array}{ll}\text { Voltage-Gated } & \mathrm{Na}+ \\
\text { Channels } & \end{array}$ & $\mathrm{NaV} \beta 3 / \mathrm{SCN} 3 \mathrm{~B}$ & $\begin{array}{l}\text { Human temporal } \\
\text { lobe epilepsy }\end{array}$ & $\begin{array}{l}\text { Human } \\
\text { hippocampus }\end{array}$ & NA & $\downarrow$ & (282) \\
\hline $\begin{array}{ll}\text { Voltage-Gated } & \mathrm{Na}+ \\
\text { Channels } & \\
\end{array}$ & $\mathrm{NaV} \beta 3 / \mathrm{SCN} 3 \mathrm{~B}$ & $\begin{array}{l}\text { Human temporal } \\
\text { lobe epilepsy }\end{array}$ & $\begin{array}{l}\text { Human } \\
\text { hippocampus }\end{array}$ & $\downarrow$ & NA & (283) \\
\hline $\begin{array}{ll}\text { Voltage-Gated } & \mathrm{K}+ \\
\text { Channels } & \\
\end{array}$ & $\mathrm{Kv7.5/KCNQ5}$ & $\begin{array}{l}\text { Human temporal } \\
\text { lobe epilepsy }\end{array}$ & Human CA1 & NA & $\downarrow$ & (256) \\
\hline $\begin{array}{ll}\text { Voltage-Gated } & \mathrm{K}+ \\
\text { Channels } & \end{array}$ & $\mathrm{Kv} 7.2 / \mathrm{KCNQ} 2$ & $\begin{array}{l}\text { Amygdala } \\
\text { kindling }\end{array}$ & Rat amygdala & NA & $\uparrow$ & (326) \\
\hline
\end{tabular}




\begin{tabular}{|c|c|c|c|c|c|c|}
\hline $\begin{array}{ll}\begin{array}{l}\text { Voltage-Gated } \\
\text { Channels }\end{array} & \mathrm{K}+ \\
\end{array}$ & $\mathrm{Kv} 4.2 / \mathrm{KCND} 2$ & Pilocarpine & Rat CA1 & NA & $\downarrow$ & (251) \\
\hline $\begin{array}{ll}\begin{array}{l}\text { Voltage-Gated } \\
\text { Channels }\end{array} & \mathrm{K}+ \\
\end{array}$ & $\mathrm{Kv} 4.2 / \mathrm{KCND} 2$ & Pilocarpine & Rat DG & NA & $\downarrow$ & (251) \\
\hline $\begin{array}{ll}\begin{array}{l}\text { Voltage-Gated } \\
\text { Channels }\end{array} & \mathrm{K}+ \\
\end{array}$ & $\mathrm{Kv} 4.2 / \mathrm{KCND} 2$ & Pilocarpine & Rat CA1 & $\downarrow$ & $\downarrow$ & (12) \\
\hline $\begin{array}{ll}\begin{array}{l}\text { Voltage-Gated } \\
\text { Channels }\end{array} & \mathrm{K}+ \\
\end{array}$ & $\mathrm{Kv} 4.2 / \mathrm{KCND} 2$ & Pilocarpine & Rat CA1, CA3 & NA & $\downarrow$ & (252) \\
\hline $\begin{array}{ll}\begin{array}{l}\text { Voltage-Gated } \\
\text { Channels }\end{array} & \mathrm{K}+ \\
\end{array}$ & Kv4.3/KCND3 & Pilocarpine & Rat DG & NA & $\leftrightarrow$ & (251) \\
\hline $\begin{array}{ll}\begin{array}{l}\text { Voltage-Gated } \\
\text { Channels }\end{array} & \mathrm{K}+ \\
\end{array}$ & KChIPl/KCNIP1 & Pilocarpine & Rat DG & NA & $\downarrow$ & (251) \\
\hline $\begin{array}{ll}\begin{array}{l}\text { Voltage-Gated } \\
\text { Channels }\end{array} & \mathrm{K}+ \\
\end{array}$ & $\mathrm{KChIPl/KCNIP1}$ & Pilocarpine & Rat CA1, CA3 & NA & $\downarrow$ & (252) \\
\hline $\begin{array}{ll}\begin{array}{l}\text { Voltage-Gated } \\
\text { Channels }\end{array} & \mathrm{K}+ \\
\end{array}$ & KChIP2/ KCNIP2 & Pilocarpine & Rat CA1 & NA & $\downarrow$ & (251) \\
\hline $\begin{array}{ll}\begin{array}{l}\text { Voltage-Gated } \\
\text { Channels }\end{array} & \mathrm{K}+ \\
\end{array}$ & KChIP2/ KCNIP2 & Pilocarpine & Rat DG & NA & $\leftrightarrow$ & (251) \\
\hline $\begin{array}{ll}\begin{array}{l}\text { Voltage-Gated } \\
\text { Channels }\end{array} & \mathrm{K}+ \\
\end{array}$ & Kv1.4/KCNA4 & Pilocarpine & Rat CA3 & NA & $\uparrow$ & (251) \\
\hline $\begin{array}{ll}\begin{array}{l}\text { Voltage-Gated } \\
\text { Channels }\end{array} & \mathrm{K}+ \\
\end{array}$ & Kv1.4/KCNA4 & Pilocarpine & Rat DG & NA & $\uparrow$ & (251) \\
\hline $\begin{array}{ll}\begin{array}{l}\text { Voltage-Gated } \\
\text { Channels }\end{array} & \mathrm{K}+\end{array}$ & Kv1.4/KCNA4 & Pilocarpine & Rat DG & NA & $\uparrow$ & (251) \\
\hline
\end{tabular}

Alterations in mRNA and protein levels of voltage-gated channels in MTLE. ${ }^{1}$ Channel family according IUPHAR classification,

${ }^{2}$ Indicates the source of data (i.e. clinical or experimental model of MTLE), ${ }^{3}$ Limbic area where experiments have been made. Abbreviations: $\uparrow$, increased levels; $\downarrow$, decreased levels; $\leftrightarrow$, no change; NA, no data found.

cells, inteneurons, gliosis, synaptic rearrangements, neurosynaptogenesis, neurogenesis (205-208) which may be manifested at different time frames after the epileptogenic insult (209-214). In fact, since the appearance of the first models of status epilepticus and epilepsy, numerous researchers have demonstrated immediate and/or long-lasting events that could modify brain excitability and result in the complex neurochemical alterations which contribute to seizure generation and spreading as well as pharmacoresistance in MTLE. These neurochemical alterations include disruption of ionic gradients across the plasma membrane, alterations in the synthesis, degradation, release and uptake of neurotransmitters, and changes in signaling pathways through the plasma membrane. More in-depth changes include synaptic remodeling and circuit changes, activation of inflammatory processes, reactive gliosis and programmed cell death (apoptosis) (215-229). However, key technological advances in the area of molecular biology during the last decade have been instrumental in desciphering the molecular aberrations underlying epileptogenesis. In this context, compelling data indicate that seizure-related modifications in expression and function of different ion channels and receptors can contribute to enhanced excitability and pharmacoresistance in epilepsy $(12,199-204,230-237)$. Accordingly, since the development of global gene expression profiling techniques, an increasing number of publications has revealed differentially expressed genes in the process of epileptogenesis. Considering clinical and experimental studies on MTLE, approximately 2000 genes have been found to show differential expression during the latent and/or chronic phase of this condition $(238,239)$. Given that the potential for complexity in genetic and molecular changes in MTLE is enormous, in this review we will focus in the changes in the expression and regulation of voltagegated ion channels in MTLE, bringing together clinical and experimental evidence. Seizure-related changes in ion channels and receptors are area of special interest for the discovery of novel targets for antiepileptic and anti- epileptogenic drugs $(240,241)$. A summary of mRNA and protein levels of voltage-gated channels is shown in Table 2.

\subsection{Potassium channels}

Potassium $\left(\mathrm{K}^{+}\right)$channels are the largest and most diverse group of ion channels, represented by some 70 known loci in the mammalian genome (242). The voltagegated $\mathrm{K}_{\mathrm{V}}$ channels, in turn, form the largest family of some 40 genes among the group of human potassium channels, which also includes the $\mathrm{Ca}^{2+}$-activated $\left(\mathrm{K}_{\mathrm{Ca}}\right)$, inwardrectifying $\left(\mathrm{K}_{\mathrm{IR}}\right)$, and two-pore $\left(\mathrm{K}_{2 \mathrm{P}}\right)$ families $(242-245)$.

Compelling data indicate that $\mathrm{K}^{+}$channels critically modulate neuronal excitability and that activation of these channels crucially affect intrinsic membrane properties and action potential firing pattern of the neurons (e.g., firing frequency) $(246,247)$. For instance, their activation limits the firing frequency of action potentials and is important for regulating afterhyperpolarization in central neurons and other types of electrically excitable cells (248). Accordingly, it has been acknowledged that depolarization-induced activation of $\mathrm{K}^{+}$channels may provide a stabilizing influence by hyperpolarizing the membrane upon opening. Hence, blocking $\mathrm{K}^{+}$channels and preventing them from opening in response to membrane depolarization decreases seizure threshold. Moreover, these channels are also expressed at presynaptic terminals, where they play a pivotal role in controlling neurotransmitter release (247-250). Therefore, deficit of $\mathrm{K}^{+}$channels has been largely implicated in the pathogenesis of neurological disorders characterized by abnormal neuronal excitability, including epilepsy (188).

In light of the view of MTLE as an acquired channelopathy, the expression of $\mathrm{K}^{+}$channels has been explored in different seizure and epilepsy models. Regarding the $\mathrm{K}_{\mathrm{V}}$ family, mRNA and/or protein levels of A-type channels (i.e., somatodendritic $\mathrm{K}_{\mathrm{V}} 4.2$, KChIP1 and 
KChIP2) are decreased in the CA1 hippocampal subfield of pilocarpine-epileptic rats $(12,251,252)$. Moreover, immunoreactivity for $\mathrm{K}_{\mathrm{V}} 4.2$ was reduced in the hippocampus of seizure-sensitive gerbils when compared to seizure-resistance ones (253). Importantly, Bernard et al. (2004) have shown a significant increase in the percent of ERK phosphorylated- $\mathrm{K}_{\mathrm{V}} 4.2$ in the hippocampal CA1 area of pilocarpine-epileptic rats. This finding indicates that post-translational modifications also contribute to hyperexcitability in MTLE, since phosphorylation of $\mathrm{K}_{\mathrm{V}} 4.2$ channels by ERK shifts the activation curve toward more positive values, which decreases dendritic $\mathrm{K}^{+}$currents (254). In addition, a $K_{V} 4.2$ channel gene mutation has been found in a MTLE patient, namely a $\mathrm{K}_{\mathrm{V}} 4.2$ truncation mutation because the identified mutation resulted in a truncated $\mathrm{K}_{\mathrm{V}} 4.2$ protein lacking the last 44 amino acids in the carboxyl-terminal (255). Interestingly, cells expressing such a $\mathrm{K}_{\mathrm{V}} 4.2$ mutant channel showed attenuated $\mathrm{K}^{+}$current density, which is consistent with increased neuronal excitability in MTLE.

Levels of other types of $\mathrm{K}_{\mathrm{V}}$ subunits have been also determined in experimental and clinical MTLE. For instance, protein levels of the $\mathrm{K}_{\mathrm{V}} 7.5$ channels are reduced in the hippocampal CA1 subfield of patients with MTLE (256). In this context, it is worth mentioning that retigabine, a new drug in development for the treatment of epilepsy, activates subtypes of $\mathrm{K}_{\mathrm{V}} 7$ channels responsible for Mcurrent in neurons $(232,257)$. Interestingly, retigabine possesses a broad spectrum anticonvulsive profile in animal seizure and epilepsy models (258-260). In contrast to the decrease in $\mathrm{K}_{\mathrm{V}} 4.2$, KChIP1, KChIP2 and $\mathrm{K}_{\mathrm{V}} 7.5$ channel subunits in pilocarpine-epileptic rats and in the epileptic human hippocampus, it has been shown that protein levels of $\mathrm{K}_{\mathrm{V}} 1.4$ are increased in the rat CA3 hippocampal subfield and dentate gyrus (DG) in the pilocarpine model of MTLE (251).

The second major group of $\mathrm{K}^{+}$-selective channels consists of the $\mathrm{K}_{\mathrm{Ca}}$ family (245). These channels are activated by rises in cytosolic calcium largely in response to calcium influx via voltage-gated calcium channels that open during action potentials (245). Therefore, $\mathrm{K}_{\mathrm{Ca}}$ are fundamental regulators of neuronal excitability, and activation of these potassium channels controls a number of physiological processes, including firing properties of neurons (i.e., interspike interval and spike-frequency adaptation) and control of transmitter release (261-265). Three broad families of calcium-activated potassium channels have been identified, which can be separated on both biophysical and pharmacological grounds (245). These have been termed BK (large conductance), SK (small conductance), and IK (intermediary conductance) channels (245). BK channels $\left(\mathrm{K}_{\mathrm{Ca}} 1.1\right)$ have recently been implicated in the pathogenesis of genetic epilepsy (266). In fact, a gain-of-function of BK channels may contribute to the epileptic phenotype (i.e., temporal lobe seizures) (267), probably by inducing rapid repolarization of action potentials, which in turn contributes to generalized epilepsy and paroxysmal dyskinesia by allowing neurons to fire at a faster rate $(266,267)$. On the other hand, the role of BK and other $\mathrm{K}_{\mathrm{Ca}}$ in acquired MTLE has begun to be determined only recently. In this context, quantitative analysis of mRNA by RT-PCR and protein levels by western blotting and immunohistochemistry of BK channels revealed that these channels are significantly reduced in the hippocampus of pilocarpine-epileptic rats when compared to age-matched non-epileptic control rats $(139,268)$. In addition, a significant down-regulation of $\mathrm{SK} 2\left(\mathrm{~K}_{\mathrm{Ca}} 2.2\right)$ and SK3 $\left(\mathrm{K}_{\mathrm{Ca}} 2.3\right)$ but not SK1 $\left(\mathrm{K}_{\mathrm{Ca}} 2.1\right)$ channel mRNA and protein was detected in samples obtained from chronic pilocarpine-epileptic rats (269). Levels of members of the $\mathrm{K}_{\mathrm{IR}}$ and $\mathrm{K}_{2 \mathrm{P}}$ families have been shown to be altered in MTLE. For instance, mRNA and protein levels of the IRK3 $\left(\mathrm{K}_{\mathrm{IR}} 2.3\right)$ channel are decreased in the temporal cortex of epileptic patients as well as in the hippocampus of pilocarpine-epileptic rats $(270,271)$. In addition, in the pilocarpine model, expression of TASK-1 $\left(\mathrm{K}_{2 \mathrm{P}} 3.1\right)$ and TASK-2 $\left(\mathrm{K}_{2 \mathrm{P}} 5.1\right)$ are decreased in the $\mathrm{DG}$ and hippocampal CA1 subfield, respectively $(272,273)$. On the other hand, it should be noted that increases in $\mathrm{K}^{+}$channels have been also found in some instances. For instance, mRNA and protein levels of the GIRK2 $\left(\mathrm{K}_{\mathrm{IR}} 3.2\right)$ channel are increased in the DG of kainate-epileptic rats (274), and TASK-2 $\left(\mathrm{K}_{2 \mathrm{P}} 5.1\right)$ immunoreactivity is increased in the CA3 subfield and DG of pilocarpine-epileptic rats (273). In addition, in a study by Young et al. (2009), protein expression of $\mathrm{K}_{\mathrm{IR}} 2$ subunits $\left(\mathrm{K}_{\mathrm{IR}} 2.1, \mathrm{~K}_{\mathrm{IR}} 2.2, \mathrm{~K}_{\mathrm{IR}} 2.3\right.$, $\mathrm{K}_{\mathrm{IR}} 2.4$ ) and of $\mathrm{K}_{2 \mathrm{P}}$ channels (Twik $1 / \mathrm{K}_{2 \mathrm{P}} 1.1$, Twik $2 / \mathrm{K}_{2 \mathrm{P}} 6.1$ ) was upregulated in granule cells taken from kainateepileptic mice (158).

\subsection{Voltage-gated sodium channels}

Voltage-gated sodium channels $\left(\mathrm{Na}_{\mathrm{V}}\right)$ are present in excitable cells, including nerve, muscle, and neuroendocrine cell types (275). $\mathrm{Na}_{\mathrm{V}}$ are members of the superfamily of ion channels that includes $\mathrm{K}_{\mathrm{V}}$ and voltagegated $\mathrm{Ca}^{2+}$ channels; however, unlike $\mathrm{K}^{+}$and $\mathrm{Ca}^{2+}$ channels, the functional properties of known sodium channels are relatively similar (275). For instance, $\mathrm{Na}_{\mathrm{V}}$ are responsible for action potential initiation with the fast, transient $\mathrm{Na}^{+}$currents $\left(I_{N a F}\right)$ and enhance neuronal repetitive firing capacity with persistent $\mathrm{Na}^{+}$currents $\left(I_{N a P}\right)$ $(276,277)$. A variety of different sodium channels has been identified by electrophysiological recording, biochemical purification, and cloning. $\mathrm{Na}_{\mathrm{V}}$ channels consist of a highly processed alpha subunit associated with auxiliary beta subunits (275). The pore-forming alpha subunit is sufficient for functional expression, but the kinetics and voltage dependence of channel gating are modified by the beta subunits (275).

It is generally believed that altered functioning of $\mathrm{Na}_{\mathrm{V}}$ may be critical in conditions leading to the alteration of neuronal excitability, basically because of the pivotal role of $\mathrm{Na}_{\mathrm{V}}$ in the modulation of neuronal firing properties. Moreover, recent genetic studies have implicated mutations in these channels in the pathogenesis of epilepsy (195-197), and these channels are common targets of antiepileptic drugs, such as phenytoin, carbamazepine and lamotrigine, possibly acting on the same binding site at clinically relevant concentrations $(240,241)$. The expression of sodium channels has been investigated in experimental MTLE as well as in the human MTLE. For instance, the 
mRNA levels for the pore-forming alpha subunit $\mathrm{Na}_{\mathrm{V}} 1.2$ was persistently down-regulated up to 30 days following status epilepticus in the DG of pilocarpine-epileptic rats (200), as well as in the human epileptic hippocampus (278). In addition, mRNA levels for $\mathrm{Na}_{\mathrm{V}} 1.6$ subunits are decreased in the rat DG in the pilocarpine model (200). On the other hand, $\mathrm{Na}_{\mathrm{V}} 1.6$ mRNA and protein levels are increased in the rat hippocampal CA1 subfield in pilocarpine-epileptic rats (279), suggesting that regional differences in the alterations in the levels of $\mathrm{Na}_{\mathrm{V}}$ subunits could exist. In addition, while Nav1.3 mRNA levels are increased in patients with MTLE (278), no alterations in this $\mathrm{Na}_{V}$ subunit were detected in the rat $\mathrm{DG}$ in the pilocarpine model of epilepsy (200). Accordingly, several idiopathic epilepsy syndromes have been associated with mutations in SCN1A (the $\mathrm{Na}_{\mathrm{V}} 1.1$ gene) (196-198), but no significant differences in the amount of $\mathrm{Na}_{\mathrm{V}} 1.1$ mRNA or protein levels have been detected in the epileptic human or rat hippocampus $(200,278,280)$.

Interestingly, reduced expression of the $\mathrm{Na}_{\mathrm{V}}$ beta 1 and beta 2 auxiliary subunits has been associated with a depolarizing shift in $\mathrm{Na}_{\mathrm{V}}$ inactivation, in such a way that the window current is amplified, resembling the increased $I_{N a P}$ seen in animal models of MTLE $(276,277)$. In this context, it has been shown that mRNA levels for the $\mathrm{Na}_{\mathrm{V}}$ beta1 but not for the beta2 subunit are decreased in the DG of pilocarpine-epileptic rats, whereas protein levels for the betal subunit are increased in the hippocampus of MTLE patients $(200,281)$. Moreover, two studies by van Gassen et al. $(2007$; 2009) showed a decrease in mRNA and protein levels of the beta3 subunit in the epileptic human hippocampus $(282,283)$.

In addition to changes in the levels of $\mathrm{Na}_{\mathrm{V}}$ subunits in MTLE, there is evidence for changes in the sensitivity of these channels to several antiepileptic drugs. In fact, the inhibitory effect of carbamazepine (CBZ) on $\mathrm{Na}^{+}$currents is decreased in DG and CA1 neurons taken from pilocarpine-epileptic rats $(201,284)$. Moreover, the CBZ-elicited blockade of the experimentally induced epileptiform activity in the epileptic DG of human hippocampal slices is much greater in a CBZ-responsive than in CBZ-resistant patients $(285,286)$. Altogether, these results indicate that the $\mathrm{Na}_{\mathrm{V}}$ channels and possibly other molecular targets for antiepileptic drugs are structurally and/or functionally modified in MTLE, undergoing a form of plasticity which contributes to pharmacoresistance (42).

\subsection{Voltage-gated calcium channels}

Voltage-gated calcium channels $\left(\mathrm{Ca}_{\mathrm{V}}\right)$ are members of a gene superfamily of transmembrane ion channel proteins that mediate calcium influx in response to membrane depolarization (287). $\mathrm{Ca}_{\mathrm{V}}$ are complex proteins composed of four or five distinct subunits that are encoded by multiple genes. The alpha ${ }_{1}$ subunit is the largest subunit, and it incorporates the conduction pore, the voltage sensor and gating apparatus, and most of the known sites of channel regulation by second messengers, drugs, and toxins (287). Most types of $\mathrm{Ca}_{\mathrm{V}}$ are composed of auxiliary alpha2delta, beta and gamma subunits, which modulate the properties of the channel complex, although the pharmacological and electrophysiological properties of $\mathrm{Ca}_{\mathrm{V}}$ arise primarily from the different alpha ${ }_{1}$ subunits (287).

Calcium currents recorded in different cell types have diverse physiological and pharmacological properties $(287,288)$. In neurons, the primarily expressed calcium currents are N-type, P/Q-type, and R-type, where they initiate neurotransmission at most fast synapses and mediate calcium entry into cell bodies and dendrites $(287,288)$. T-type calcium currents are also expressed in neurons, and they are involved in shaping the action potential and controlling patterns of repetitive firing $(287,288)$. In addition, L-type calcium currents, the main calcium currents recorded in muscle and endocrine cells, are also seen in neurons $(287,288)$.

The expression levels $\mathrm{Ca}_{\mathrm{V}}$ has been investigated in clinical and experimental MTLE. In a study by Becker et al. (2008), mRNA and protein levels of different T-typeforming alpha subunits were evaluated. The mRNA and protein levels for alpha ${ }_{1 \mathrm{G}}\left(\mathrm{Ca}_{\mathrm{V}} 3.1\right)$ or alpha $\mathrm{II}_{\mathrm{II}}\left(\mathrm{Ca}_{\mathrm{V}} 3.3\right)$ were not altered in the hippocampal CA1 subfield of pilocarpineepileptic mice, but levels of alpha ${ }_{1 \mathrm{H}}\left(\mathrm{Ca}_{\mathrm{V}} 3.2\right)$ mRNA and protein were significantly upregulated (289). Interestingly, the appearance of spontaneous seizures was dramatically reduced in $\mathrm{Ca}_{\mathrm{V}} 3.2$ knockout mice, suggesting transcriptional induction of this T-type calcium channel as a critical step in epileptogenesis in the pilocarpine model of epilepsy. In addition, it has been shown that immunostaining for the alpha $\mathrm{IC}_{\mathrm{C}}\left(\mathrm{Ca}_{\mathrm{V}} 1.2\right)$ and $\mathrm{alpha}_{1 \mathrm{D}}$ $\left(\mathrm{Ca}_{\mathrm{V}} 1.3\right)$ subunits (which form L-type channels) and of the alpha $_{1 \mathrm{~A}}$ subunit (which form P/Q-type channels) are increased in the mice DG in the pilocarpine model of epilepsy (290). Moreover, increased mRNA levels of the alpha $_{1 \mathrm{~A}}\left(\mathrm{Ca}_{\mathrm{V}} 2.1\right)$ subunit has been found in the DG of kainate-epileptic rats (291).

In temporal lobe epilepsy patients with Ammon's horn sclerosis, an increased immunoreactivity was observed for alpha $\mathrm{A}_{\mathrm{A}}\left(\mathrm{Ca}_{\mathrm{V}} 2.1\right)$, alpha $\mathrm{B}_{\mathrm{B}}\left(\mathrm{Ca}_{\mathrm{V}} 2.2\right)$, alpha $\left(\mathrm{Ca}_{\mathrm{V}} 1.3\right)$ and alpha $_{1 \mathrm{E}}\left(\mathrm{Ca}_{\mathrm{V}} 2.3\right)$ in the $\mathrm{DG}$, whereas immunoreactivity for the alpha ${ }_{1 \mathrm{~A}}\left(\mathrm{Ca}_{\mathrm{V}} 2.1\right)$ and alpha ${ }_{1 \mathrm{C}}$ $\left(\mathrm{Ca}_{\mathrm{V}} 1.2\right)$ were respectively increased and decreased in the CA3 subfield (292). Moreover, in the severely sclerotic Ammon's horn subfields of MTLE patients, beta1 and beta2 immunoreactivity was enhanced in some of the remaining neuronal cell bodies (293), indicating that $\mathrm{Ca}_{V}$ auxiliary beta subunits are also altered in MTLE.

\subsection{Cyclic nucleotide-regulated channels}

The cyclic nucleotide-regulated channel family comprises two groups of ion channels, the cyclic nucleotide-gated (CNG) and the hyperpolarizationactivated, cyclic nucleotide-gated $(\mathrm{HCN})$ channels. In this review we will focus in the HCN channels, since they are widely distributed in the central nervous system, and an increasing number of studies have mechanistically linked changes in the expression of HCN channels to absence epilepsy and MTLE (199,204,294-299).

The HCN channel family comprises four members (HCN1-HCN4) (300). All HCN channels contain 
six-transmembrane helices (S1-S6) and assemble in tetramers (300). The S4 segment of the channels is positively charged and serves as voltage sensor, while the $\mathrm{C}$ terminus contains a cyclic nucleotide binding domain that confers regulation by the cyclic nucleotides cGMP and cAMP (300). Interestingly, the stimulatory effect of cyclic nucleotides does not depend on protein phosphorylation but is caused by direct interaction with the HCN channel protein (300).

The current produced by HCN channels, commonly termed $I_{h}$, is found in a variety of excitable cells, including neurons, cardiac pacemaker cells, and photoreceptors $(300,301)$. In neurons, $I_{h}$ is critically involved in modulation of excitability by determining resting potential and generating "pacemaker potentials" (300-302). The typical features of $I_{h}$ include activation by membrane hyperpolarization; permeation of $\mathrm{Na}^{+}$and $\mathrm{K}^{+}$; and positive shift of voltage dependence of channel activation by direct binding of cyclic nucleotides $(300,301)$.

Interestingly, both decreases and increases in HCN channel expression have been shown to occur in multiple animal models of MTLE as well as epileptic humans. In fact, mRNA and protein levels for the HCN1 channel subtype were found to be decreased in rat CA1 hippocampal subfield in the pilocarpine as well as in the kainate model of MTLE $(199,204,303)$. On the other hand, increases in mRNA and protein levels for HCN1 have been shown in the human epileptic DG and also in the DG of pilocarpine epileptic rats (294). Regarding changes in the HCN2 channel subtype, it has been shown that mRNA for but not protein levels of this channel were decreased in the rat CA1 hippocampal subfield in pilocarpine-epileptic rats (204). In addition, mRNA levels for HCN2 were decreased in CA1 area and DG in the hippocampus of kainate-epileptic rats (295). However, no changes in HCN2 mRNA or protein levels have been found in the rat DG in the pilocarpine model as well as in the same area in the hippocampus of MTLE patients (294). Moreover, in the amygdala kindling model of MTLE, no changes in mRNA and protein levels for $\mathrm{HCN} 1$ or $\mathrm{HCN} 2$ have been found in rat hippocampal CA1 subfield or DG (295).

Interestingly, enhanced neuronal excitability during kainate-induced MTLE in the entorhinal layer III is accompanied by a decrease in the $I_{\mathrm{h}}(304)$. Moreover, a down-regulation in $I_{h}$ has been also demonstrated in the hippocampus of pilocarpine-epileptic animals $(199,204)$. These results are surprising because $I_{h}$ depolarizes the resting membrane potential (300-302) and, hence, a decline in $I_{\mathrm{h}}$ might be expected to reduce excitability. However, $I_{\mathrm{h}}$ inhibition has been suggested to enhance pyramidal cell dendritic excitability by increasing the availability of $\mathrm{Ca}^{2+}$ channels (305), as well as by amplifying the membrane resistance $(306,307)$. In this context, it is important to point out that $I_{h}$ blockers, such as ZD7288 and $\mathrm{CsCl}$ have been shown to decrease electrically induced paroxysmal discharges in vivo, suggesting antiepileptic effects for compounds that decrease the $I_{h}(308)$.

\section{SUMMARY AND PERSPECTIVES}

A wealth of supporting evidence indicate that the limbic system exhibits a low threshold for developing acute and chronic epileptiform activity, in some cases eventually leading to a state of enhanced excitability as in MTLE. Epileptiform activity in general is characterized by evoked and spontaneous PDS, burst of action potentials and associated poly-spiking activity in extracellular recordings. These electrophysiological abnormalities have been largely considered as the electrophysiological landmarks of interictal spikes in epilepsy. Despite stereotyped patterns of epileptiform activity, the pathogenic mechanisms leading to hyperexcitability are diverse and highly complex in acquired or symptomatic epilepsy. In contrast to genetic channelopathies, in which a mutation of a specific ion channel or receptor is thought to contribute to the epileptic phenotype, acquired epilepsy as MTLE is characterized by numerous, in most cases concurrent, alterations in the expression and function of ion channels and receptors. Furthermore, the precise combinations of abnormalities leading to more aggressive epileptic phenotypes or pharmacoresistance remain to be elucidated. Detection of these molecular and functional deficits in human epilepsy may play a predictive key role in assessing the pathogenesis of the disease in certain populations of patients. Accordingly, detection of these molecular abnormalities by non-invasive or minimally invasive assays may allow the development of tests to investigate predictive biomarkers of progression, intractability and prognosis in acquired epilepsies of difficult control as MTLE.

\section{ACKNOWLEDGMENTS}

E.R.G.S and L.F.P.O are supported by P20MD001091 (NIH/NCMHD), R21NS056160-01A2 (NIH/NINDS), 5SC1NS063950-04 (NIH/NIGMS/MBRS) and 3SC1NS063950-03S1, USA; C.F.M and M.S.O are supported by CNPq and CAPES (grants 476551/2009-9, $301552 / 2007-0$ and 150905/2009-2), Brazil, and E.A.C. is supported by FAPESP (CInAPCe program) and CNPq/MCT/FAPESP (INCT program), Brazil.

\section{REFERENCES}

1. WT Blume, HO Luders, E Mizrahi, C Tassinari, W van Emde Boas, J Engel Jr.: Glossary of descriptive terminology for ictal semiology: report of the ILAE task force on classification and terminology. Epilepsia 42, 1212-1218 (2001)

2. J Engel Jr, A Berg, F Andermann, G Avanzini, S Berkovic, W Blume, O Dulac, W van Emde Boas, N Fejerman, P Plouin, I Scheffer, M Seino, P Williamson, P Wolf: Are epilepsy classifications based on epileptic syndromes and seizure types outdated? Epileptic Disord 8, 159-160 (2006)

3. RS Fisher, W van Emde Boas, W Blume, C Elger, P Genton, P Lee, J Engel Jr.: Epileptic seizures and epilepsy: definitions proposed by the International League Against 
Epilepsy (ILAE) and the International Bureau for Epilepsy (IBE). Epilepsia 46, 470-472 (2005)

4. Epilepsy ILA. RESEARCH PRIORITIES IN EPILEPSY FOR THE NEXT DECADE-A REPRESENTATIVE VIEW OF THE EUROPEAN SCIENTIFIC COMMUNITY. Summary of the ILAE Epilepsy Research Workshop, Brussels, 17-18 January 2008.

5. K Stavem, H Bjornaes, IA Langmoen: Predictors of seizure outcome after temporal lobectomy for intractable epilepsy. Acta Neurol Scand 109, 244-249 (2004)

6. R Surtees: Inherited ion channel disorders. Eur J Pediatr 159, S199-203 (2000)

7. RL Barchi: Ion channel mutations affecting muscle and brain. Curr Opin Neurol 11, 461-468 (1998)

8. K Staley, JL Hellier, FE Dudek: Do interictal spikes drive epileptogenesis? Neuroscientist 11, 272-276 (2005)

9. JS Ebersole, RA Levine: Abnormal neuronal responses during evolution of a penicillin epileptic focus in cat visual cortex. J Neurophysiol 38, 250-256 (1975)

10. GF Ayala: The paroxysmal depolarizing shift. Prog Clin Biol Res 124, 15-21 (1983)

11. NP Poolos: The h-channel: a potential channelopathy in epilepsy? Epilepsy Behav 7, 51-56 (2005)

12. C Bernard, A Anderson, A Becker, NP Poolos, H Beck, D Johnston: Acquired dendritic channelopathy in temporal lobe epilepsy. Science 305, 532-535 (2004)

13. MP Jacobs, GG Leblanc, A Brooks-Kayal, FE Jensen, DH Lowenstein, JL Noebels, DD Spencer, JW Swann: Curing epilepsy: progress and future directions. Epilepsy Behav 14, 438-445 (2009)

14. S Arroyo, MJ Brodie, G Avanzini, C Baumgartner, C Chiron, O Dulac, JA French, JM Serratosa: Is refractory epilepsy preventable? Epilepsia 43, 437-444 (2002)

15. F Semah, P Ryvlin: Can we predict refractory epilepsy at the time of diagnosis? Epileptic Disord 7, S10-13 (2005)

16. DT Depositario-Cabacar, JJ Riviello, M Takeoka: Present status of surgical intervention for children with intractable seizures. Curr Neurol Neurosci Rep 8, 123-129 (2008)

17. MJ Brodie: Diagnosing and predicting refractory epilepsy. Acta Neurol Scand Suppl 181, 36-39 (2005)

18. P Kwan, MJ Brodie: Early identification of refractory epilepsy. N Engl J Med 342, 314-319 (2000)

19. H Clusmann: Predictors, procedures, and perspective for temporal lobe epilepsy surgery. Semin Ultrasound CT MR 29, 60-70 (2008)
20. DW Kim, SK Lee, K Chu, KI Park, SY Lee, CH Lee, CK Chung, G Choe, JY Kim: Predictors of surgical outcome and pathologic considerations in focal cortical dysplasia. Neurology 72, 211-216 (2009)

21. J Engel Jr: Progress in epilepsy: reducing the treatment gap and the promise of biomarkers. Curr Opin Neurol 21, 150-154 (2008)

22. I Savic, S Pauli, JO Thorell, G Blomqvist: In vivo demonstration of altered benzodiazepine receptor density in patients with generalised epilepsy. J Neurol Neurosurg Psychiatry 57, 797-804 (1994)

23. I Savic, L Widen, JO Thorell, G Blomqvist, K Ericson, $P$ Roland: Cortical benzodiazepine receptor binding in patients with generalized and partial epilepsy. Epilepsia 31, 724-730 (1990)

24. I Savic, A Persson, P Roland, S Pauli, G Sedvall, L Widen: In-vivo demonstration of reduced benzodiazepine receptor binding in human epileptic foci. Lancet 2, 863-866 (1988)

25. AS Basile, BA Weissman, Skolnick P: Maximal electroshock increases the density of $3 \mathrm{H}) \mathrm{Ro} 5-4864$ binding to mouse cerebral cortex. Brain Res Bull 19, 1-7 (1987)

26. EF Berman, MW Adler: The anticonvulsant effect of opioids and opioid peptides against maximal electroshock seizures in rats. Neuropharmacology 23, 367-371 (1984)

27. LK Desmedt, CJ Niemegeers, PA Janssen: Anticonvulsive properties of cinnarizine and flunarizine in rats and mice. Arzneimittelforschung 25, 1408-1413 (1975)

28. W Loscher, CP Fassbender, B Nolting: The role of technical, biological and pharmacological factors in the laboratory evaluation of anticonvulsant drugs. II. Maximal electroshock seizure models. Epilepsy Res 8, 79-94 (1991)

29. HS White, M Johnson, HH Wolf, HJ Kupferberg: The early identification of anticonvulsant activity: role of the maximal electroshock and subcutaneous pentylenetetrazol seizure models. Ital J Neurol Sci 16, 73-77 (1995)

30. GC Palmer, ML Stagnitto, JM Ordy, RC Griffith, JJ Napier, RJ Gentile, JH Woodhead, HS White, EA Swinyard: Preclinical profile of stereoisomers of the anticonvulsant remacemide in mice. Epilepsy Res 8, 36-48 (1991)

31. E Shek, T Murakami, C Nath, E Pop, NS Bodor: Improved anticonvulsant activity of phenytoin by a redox brain delivery system. III: Brain uptake and pharmacological effects. J Pharm Sci 78, 837-843 (1989)

32. JD Leander, DW Robertson, CR Clark, RR Lawson, RC Rathbun: Pharmacological effects of enantiomers of 4amino-N- (alpha-methylbenzyl)benzamide, a chemically novel anticonvulsant. Epilepsia 29, 83-90 (1988) 
33. N Siddiqui, W Ahsan: Triazole incorporated thiazoles as a new class of anticonvulsants: Design, synthesis and in vivo screening. Eur J Med Chem 45, 1536-1543 (2010)

34. N Siddiqui, W Ahsan: Benzothiazole incorporated barbituric acid derivatives: synthesis and anticonvulsant screening. Arch Pharm (Weinheim) 342, 462-468 (2009)

35. JJ Luszczki, KM Sawicka, J Kozinska, M DudraJastrzebska, SJ Czuczwar: Amiloride enhances the anticonvulsant action of various antiepileptic drugs in the mouse maximal electroshock seizure model. J Neural Transm 116, 57-66 (2009)

36. A Talevi, CL Bellera, EA Castro, LE Bruno-Blanch: A successful virtual screening application: prediction of anticonvulsant activity in MES test of widely used pharmaceutical and food preservatives methylparaben and propylparaben. J Comput Aided $\mathrm{Mol}$ Des 21, 527-538 (2007)

37. KK Borowicz, JJ Luszczki, G Sobieszek, N Ratnaraj, PN Patsalos, SJ Czuczwar: Interactions between zonisamide and conventional antiepileptic drugs in the mouse maximal electroshock test model. Eur Neuropsychopharmacol 17, 265-272 (2007)

38. W Fischer, H Kittner, R Regenthal, E Russo, G De Sarro: Effects of piracetam alone and in combination with antiepileptic drugs in rodent seizure models. J Neural Transm 111, 1121-1139 (2004)

39. W Loscher: Animal models of epilepsy for the development of antiepileptogenic and disease-modifying drugs. A comparison of the pharmacology of kindling and post-status epilepticus models of temporal lobe epilepsy. Epilepsy Res 50, 105-123 (2002)

40. GL Holmes, Q Zhao: Choosing the correct antiepileptic drugs: from animal studies to the clinic. Pediatr Neurol 38, 151-162 (2008)

41. EA van Vliet, R van Schaik, PM Edelbroek, FH da Silva, WJ Wadman, JA Gorter: Development of tolerance to levetiracetam in rats with chronic epilepsy. Epilepsia 49 , 1151-1159 (2008)

42. H Beck: Plasticity of antiepileptic drug targets: Epilepsia 48, S14-18 (2007)

43. JE Pina-Garza, DR Nordli Jr, D Rating, H Yang, J Schiemann-Delgado, B Duncan: Adjunctive levetiracetam in infants and young children with refractory partial-onset seizures. Epilepsia 50, 1141-1149 (2009)

44. J Peltola, C Coetzee, F Jimenez, T Litovchenko, S Ramaratnam, L Zaslavaskiy, ZS Lu, DM Sykes: Once-daily extended-release levetiracetam as adjunctive treatment of partial-onset seizures in patients with epilepsy: a doubleblind, randomized, placebo-controlled trial. Epilepsia 50, 406-414 (2009)
45. S Li, J Cao, N Xiao, F Cai: Efficacy and Safety of Levetiracetam as an Add-On Therapy in Children Aged Less Than 4 Years With Refractory Epilepsy. J Child Neurol 25, 609-613 (2009)

46. DS Ledet, JW Wheless, JE Rubnitz, E Brannon Morris: Levetiracetam as monotherapy for seizures in a neonate with acute lymphoblastic leukemia. Eur J Paediatr Neurol 14, 78-79 (2010)

47. U Kramer, L Sagi, H Goldberg-Stern, N Zelnik, A Nissenkorn, B Ben-Zeev: Clinical spectrum and medical treatment of children with electrical status epilepticus in sleep (ESES). Epilepsia 50, 1517-1524 (2009)

48. PC Giroux, M Salas-Prato, Y Theoret, L Carmant: Levetiracetam in children with refractory epilepsy: lack of correlation between plasma concentration and efficacy. Seizure 18, 559-563 (2009)

49. S Berning, F Boesebeck, A van Baalen, C Kellinghaus: Intravenous levetiracetam as treatment for status epilepticus. J Neurol 256, 1634-1642 (2009)

50. A Verrotti, C Cerminara, S Domizio, A Mohn, E Franzoni, G Coppola, N Zamponi, P Parisi, P Iannetti, P Curatolo: Levetiracetam in absence epilepsy. Dev Med Child Neurol 50, 850-853 (2008)

51. A Verrotti, C Cerminara, G Coppola, E Franzoni, P Parisi, P Iannetti, P Aloisi, E Tozzi, R Cusmai, F Vigevano, F Chiarelli, P Curatolo. Levetiracetam in juvenile myoclonic epilepsy: long-term efficacy in newly diagnosed adolescents. Dev Med Child Neurol 50, 29-32 (2008)

52. DV Sharpe, AD Patel, B Abou-Khalil, GM Fenichel: Levetiracetam monotherapy in juvenile myoclonic epilepsy. Seizure 17, 64-68 (2008)

53. RM Kaminski, A Matagne, $\mathrm{K}$ Leclercq, $\mathrm{M}$ Gillard, $\mathrm{P}$ Michel, B Kenda, P Talaga, H Klitgaard: SV2A protein is a broad-spectrum anticonvulsant target: functional correlation between protein binding and seizure protection in models of both partial and generalized epilepsy. Neuropharmacology 54, 715-720 (2008)

54. C Johannessen Landmark, SI Johannessen: Pharmacological management of epilepsy: recent advances and future prospects. Drugs 68, 1925-1939 (2008)

55. JS Goraya, DS Khurana, I Valencia, JJ Melvin, M Cruz, A Legido, SV Kothare: Intravenous levetiracetam in children with epilepsy. Pediatr Neurol 38, 177-180 (2008)

56. A Gambardella, A Labate, E Colosimo, R Ambrosio, A Quattrone: Monotherapy for partial epilepsy: focus on levetiracetam. Neuropsychiatr Dis Treat 4, 33-38 (2008)

57. H Klitgaard: Levetiracetam: the preclinical profile of a new class of antiepileptic drugs? Epilepsia 42, S13-S8 (2001) 
58. CM Ulloa, A Towfigh, J Safdieh: Review of levetiracetam, with a focus on the extended release formulation, as adjuvant therapy in controlling partial-onset seizures. Neuropsychiatr Dis Treat 5, 467-476 (2009)

59. S Amano, N Ihara, S Uemura, M Yokoyama, M Ikeda, T Serikawa, M Sasahara, H Kataoka, Y Hayase, F Hazama: Development of a novel rat mutant with spontaneous limbic-like seizures. Am J Pathol 149, 329-336 (1996)

60. S Amano, N Ihara, S Uemura, M Yokoyama, M Ikeda, F Hazama: Neuropathological study on a newly developed epileptic rat mutant with limbic-like seizures. Psychiatry Clin Neurosci 49, S284-286 (1995)

61. GV Goddard, RM Douglas: Does the engram of kindling model the engram of normal long term memory? Can J Neurol Sci 2, 385-394 (1975)

62. N Cullen, GV Goddard: Kindling in the hypothalamus and transfer to the ipsilateral amygdala. Behav Biol 15, 119-131 (1975)

63. JA Wada: Kindling as a model of epilepsy: Electroencephalogr Clin Neurophysiol Suppl 34, 309-316 (1978)

64. JO McNamara, MC Byrne, RM Dasheiff, JG Fitz: The kindling model of epilepsy: a review. Prog Neurobiol 15, 139-159 (1980)

65. RG Perrin, HJ Hoffman: Temporal lobe epilepsy and kindling. Bol Estud Med Biol 30, 197-200 (1979)

66. K Morimoto, GV Goddard: Seizure-triggering mechanism in the kindling model of epilepsy: I. EEG changes during stimulation from the site of stimulation. Jpn J Psychiatry Neurol 42, 618-619 (1988)

67. E Maru, GV Goddard: Alteration in dentate neuronal activities associated with perforant path kindling. II. Decrease in granule cell excitability. Exp Neurol 96, 33-45 (1987)

68. K Morimoto, GV Goddard: Kindling induced changes in EEG recorded during stimulation from the site of stimulation: collapse of GABA-mediated inhibition and onset of rhythmic synchronous burst. Exp Neurol 94, 571584 (1986)

69. JC McEachern, CA Shaw: The plasticity-pathology continuum: defining a role for the LTP phenomenon. $J$ Neurosci Res 58, 42-61 (1999)

70. B Adams, M Lee, M Fahnestock, RJ Racine: Long-term potentiation trains induce mossy fiber sprouting. Brain Res 775, 193-197 (1997)

71. G Golarai, TP Sutula: Functional alterations in the dentate gyrus after induction of long-term potentiation, kindling, and mossy fiber sprouting. J Neurophysiol 75 , 343-353 (1996)

72. LW Leung: Evaluation of the hypothesis that hippocampal interictal spikes are caused by long-term potentiation. Epilepsia 35, 785-794 (1994)

73. DP Cain: Long-term potentiation and kindling: how similar are the mechanisms? Trends Neurosci 12, 6-10 (1989)

74. DC McIntyre, KL Gilby: Kindling as a model of human epilepsy. Can J Neurol Sci 36, S33-35 (2009)

75. E Bertram: The relevance of kindling for human epilepsy. Epilepsia 48, 65-74 (2007)

76. ME Gilbert: Does the kindling model of epilepsy contribute to our understanding of multiple chemical sensitivity? Ann N Y Acad Sci 933, 68-91 (2001)

77. SK Kulkarni, B George: Kindling model of epilepsy. Methods Find Exp Clin Pharmacol 16, 735-745 (1994)

78. J Majkowski: Kindling: a model for epilepsy and memory. Acta Neurol Scand Suppl 109, 97-108 (1986)

79. JO McNamara: Kindling model of epilepsy. Adv Neurol 44, 303-318 (1986)

80. JO McNamara, DW Bonhaus, C Shin, BJ Crain, RL Gellman, JL Giacchino: The kindling model of epilepsy: a critical review. CRC Crit Rev Clin Neurobiol 1, 341-391 (1985)

81. JO McNamara: Kindling: an animal model of complex partial epilepsy. Ann Neurol 16, S72-76 (1984)

82. J Tuunanen, $\mathrm{T}$ Halonen, A Pitkanen: Decrease in somatostatin-immunoreactive neurons in the rat amygdaloid complex in a kindling model of temporal lobe epilepsy. Epilepsy Res 26, 315-327 (1997)

83. TP Sutula, JE Cavazos, AR Woodard: Long-term structural and functional alterations induced in the hippocampus by kindling: implications for memory dysfunction and the development of epilepsy. Hippocampus 4, 254-258 (1994)

84. TP Sutula: Reactive changes in epilepsy: cell death and axon sprouting induced by kindling. Epilepsy Res 10, 62-70 (1991)

85. TP Sutula: Experimental models of temporal lobe epilepsy: new insights from the study of kindling and synaptic reorganization. Epilepsia 31, S45-54 (1990)

86. DA Rempe, PS Mangan, EW Lothman: Regional heterogeneity of pathophysiological alterations in CA1 and dentate gyrus in a chronic model of temporal lobe epilepsy. J Neurophysiol 74, 816-828 (1995) 
87. PS Mangan, DA Rempe, EW Lothman: Changes in inhibitory neurotransmission in the CA1 region and dentate gyrus in a chronic model of temporal lobe epilepsy. $J$ Neurophysiol 74, 829-840 (1995)

88. EW Lothman, DA Rempe, PS Mangan: Changes in excitatory neurotransmission in the CA1 region and dentate gyrus in a chronic model of temporal lobe epilepsy. $J$ Neurophysiol 74, 841-848 (1995)

89. EW Lothman, EH Bertram, J Kapur, JL Stringer: Recurrent spontaneous hippocampal seizures in the rat as a chronic sequela to limbic status epilepticus. Epilepsy Res 6, 110-118 (1990)

90. EW Lothman, EH Bertram, JW Bekenstein, JB Perlin: Self-sustaining limbic status epilepticus induced by 'continuous' hippocampal stimulation: electrographic and behavioral characteristics. Epilepsy Res 3, 107-119 (1989)

91. J Nissinen, T Halonen, E Koivisto, A Pitkanen: A new model of chronic temporal lobe epilepsy induced by electrical stimulation of the amygdala in rat. Epilepsy Res 38, 177-205 (2000)

92. A Pitkanen, J Nissinen, K Lukasiuk, L Jutila, L Paljarvi, T Salmenpera, K Karkola, M Vapalahti, A Ylinen: Association between the density of mossy fiber sprouting and seizure frequency in experimental and human temporal lobe epilepsy. Epilepsia 41, S24-29 (2000)

93. C Brandt, M Glien, H Potschka, H Volk, W Loscher: Epileptogenesis and neuropathology after different types of status epilepticus induced by prolonged electrical stimulation of the basolateral amygdala in rats. Epilepsy Res 55, 83-103 (2003)

94. JL Stringer, JM Williamson, EW Lothman: Induction of paroxysmal discharges in the dentate gyrus: frequency dependence and relationship to afterdischarge production. $J$ Neurophysiol 62, 126-135 (1989)

95. JW Olney, V Rhee, OL Ho: Kainic acid: a powerful neurotoxic analogue of glutamate. Brain Res 77, 507-512 (1974)

96. R Zaczek, M Nelson, JT Coyle: Kainic acid neurotoxicity and seizures. Neuropharmacology 20, 183-189 (1981)

97. Y Ben-Ari, E Tremblay, D Riche, G Ghilini, R Naquet: Electrographic, clinical and pathological alterations following systemic administration of kainic acid, bicuculline or pentetrazole: metabolic mapping using the deoxyglucose method with special reference to the pathology of epilepsy. Neuroscience 6, 1361-1391 (1981)

98. JV Nadler, BW Perry, CW Cotman: Intraventricular kainic acid preferentially destroys hippocampal pyramidal cells. Nature 271, 676-677 (1978)

99. Y Ben-Ari, J Lagowska, E Tremblay, G Le Gal La Salle: A new model of focal status epilepticus: intra- amygdaloid application of kainic acid elicits repetitive secondarily generalized convulsive seizures. Brain Res 163 , 176-179 (1979)

100. Y Ben-Ari, E Tremblay, OP Ottersen: Injections of kainic acid into the amygdaloid complex of the rat: an electrographic, clinical and histological study in relation to the pathology of epilepsy. Neuroscience 5, 515-528 (1980)

101. MF Nelson, R Zaczek, JT Coyle: Effects of sustained seizures produced by intrahippocampal injection of kainic acid on noradrenergic neurons: evidence for local control of norepinephrine release. J Pharmacol Exp Ther 214, 694$702(1980)$

102. C Menini, BS Meldrum, D Riche, C Silva-Comte, JM Stutzmann: Sustained limbic seizures induced by intraamygdaloid kainic acid in the baboon: Symptomatology and neuropathological consequences. Ann Neurol 8, 501-509 (1980)

103. T Tanaka, M Kaijima, G Daita, S Ohgami, Y Yonemasu, D Riche: Electroclinical features of kainic acidinduced status epilepticus in freely moving cats. Microinjection into the dorsal hippocampus. Electroencephalogr Clin Neurophysiol 54, 288-300 (1982)

104. Y Ben-Ari, E Tremblay, OP Ottersen, BS Meldrum: The role of epileptic activity in hippocampal and "remote" cerebral lesions induced by kainic acid. Brain Res 191, 7997 (1980)

105. M Pisa, PR Sanberg, ME Corcoran, HC Fibiger: Spontaneously recurrent seizures after intracerebral injections of kainic acid in rat: a possible model of human temporal lobe epilepsy. Brain Res 200, 481-487 (1980)

106. JV Nadler: Kainic acid as a tool for the study of temporal lobe epilepsy. Life Sci 29, 2031-2042 (1981)

107. EW Lothman, RC Collins, JA Ferrendelli: Kainic acid-induced limbic seizures: electrophysiologic studies. Neurology 31, 806-812 (1981)

108. EW Lothman, RC Collins: Kainic acid induced limbic seizures: metabolic, behavioral, electroencephalographic and neuropathological correlates. Brain Res 218, 299-318 (1981)

109. TJ Ashwood, B Lancaster, HV Wheal: Intracellular electrophysiology of CA1 pyramidal neurones in slices of the kainic acid lesioned hippocampus of the rat. Exp Brain Res 62, 189-198 (1986)

110. S Nakajima, JE Franck, D Bilkey, PA Schwartzkroin: Local circuit synaptic interactions between CA1 pyramidal cells and interneurons in the kainate-lesioned hyperexcitable hippocampus. Hippocampus 1, 67-78 (1991)

111. EA Cavalheiro, DA Riche, G Le Gal La Salle: Longterm effects of intrahippocampal kainic acid injection in 
rats: a method for inducing spontaneous recurrent seizures. Electroencephalogr Clin Neurophysiol 53, 581-589 (1982)

112. RS Sloviter, BP Damiano: On the relationship between kainic acid-induced epileptiform activity and hippocampal neuronal damage. Neuropharmacology 20, 1003-1011 (1981)

113. R Naquet, B Meldrum, Y Ben-Ari: Hippocampal lesions and status epilepticus. Electroencephalogr Clin Neurophysiol Suppl 35, 171-183 (1982)

114. Y Ben-Ari, A Represa, E Tremblay, O Robain, G Le Gal La Salle, C Rovira, $M$ Gho, E Cherubini: Epileptogenesis and neuronal plasticity: studies on kainate receptor in the human and rat hippocampus. Epilepsy Res Suppl 8, 369-373 (1992)

115. LD Cahan, JW Geddes, BH Choi, C Cotman: Excitotoxic amino acid receptors in human complex partial epilepsy. Stereotact Funct Neurosurg 54-55, 21-24 (1990)

116. AC Foster: Involvement of excitatory amino acid receptors in the mechanisms underlying excitotoxic phenomena. Adv Exp Med Biol 203, 303-316 (1986)

117. JT Coyle, R Zaczek, J Slevin, J Collins: Neuronal receptor sites for kainic acid: correlations with neurotoxicity. Adv Biochem Psychopharmacol 27, 337-346 (1981)

118. WA Turski, EA Cavalheiro, M Schwarz, SJ Czuczwar, Z Kleinrok, L Turski: Limbic seizures produced by pilocarpine in rats: behavioural, electroencephalographic and neuropathological study. Behav Brain Res 9, 315-335 (1983)

119. DB Clifford, JW Olney, A Maniotis, RC Collins, CF Zorumski: The functional anatomy and pathology of lithium-pilocarpine and high-dose pilocarpine seizures. Neuroscience 23, 953-968 (1987)

120. Z Liu, T Nagao, GC Desjardins, P Gloor, M Avoli: Quantitative evaluation of neuronal loss in the dorsal hippocampus in rats with long-term pilocarpine seizures. Epilepsy Res 17, 237-247 (1994)

121. LM Tetz, PE Rezk, RH Ratcliffe, RK Gordon, KE Steele, MP Nambiar: Development of a rat pilocarpine model of seizure/status epilepticus that mimics chemical warfare nerve agent exposure. Toxicol Ind Health 22, 255266 (2006)

122. RA Morrisett, RS Jope, OC Snead $3^{\text {rd }}$ : Status epilepticus is produced by administration of cholinergic agonists to lithium-treated rats: comparison with kainic acid. Exp Neurol 98, 594-605 (1987)

123. RA Morrisett, RS Jope, OC Snead $3^{\text {rd }}$ : Effects of drugs on the initiation and maintenance of status epilepticus induced by administration of pilocarpine to lithiumpretreated rats. Exp Neurol 97, 193-200 (1987)
124. V Andre, A Ferrandon, C Marescaux, A Nehlig: The lesional and epileptogenic consequences of lithiumpilocarpine-induced status epilepticus are affected by previous exposure to isolated seizures: effects of amygdala kindling and maximal electroshocks. Neuroscience 99, 469481 (2000)

125. B Noyan, G Gulec: Effects of L-arginine on prevention and treatment of lithium-pilocarpine-induced status epilepticus. Physiol Res 49, 379-385 (2000)

126. V Andre, A Ferrandon, C Marescaux, A Nehlig: Vigabatrin protects against hippocampal damage but is not antiepileptogenic in the lithium-pilocarpine model of temporal lobe epilepsy. Epilepsy Res 47, 99-117 (2001)

127. V Andre, C Marescaux, A Nehlig, JM Fritschy: Alterations of hippocampal GAbaergic system contribute to development of spontaneous recurrent seizures in the rat lithium-pilocarpine model of temporal lobe epilepsy. Hippocampus 11, 452-468 (2001)

128. DW Cadotte, B Xu, RJ Racine, GM MacQueen, JF Wang, B McEwen, LT Young: Chronic lithium treatment inhibits pilocarpine-induced mossy fiber sprouting in rat hippocampus. Neuropsychopharmacology 28, 1448-1453 (2003)

129. MA Persinger, MJ Dupont: Emergence of spontaneous seizures during the year following lithium/pilocarpine-induced epilepsy and neuronal loss within the right temporal cortices. Epilepsy Behav 5, 440-445 (2004)

130. MA Rigoulot, E Koning, A Ferrandon, A Nehlig: Neuroprotective properties of topiramate in the lithiumpilocarpine model of epilepsy. J Pharmacol Exp Ther 308, 787-795 (2004)

131. V Andre, C Dube, J Francois, C Leroy, MA Rigoulot, C Roch, IJ Namer, A Nehlig: Pathogenesis and pharmacology of epilepsy in the lithium-pilocarpine model. Epilepsia 48, S41-47 (2007)

132. RS Jope, RA Morrisett, OC Snead: Characterization of lithium potentiation of pilocarpineinduced status epilepticus in rats. Exp Neurol 91, 471480 (1986)

133. CJ Muller, M Bankstahl, I Groticke, W Loscher: Pilocarpine vs. lithium-pilocarpine for induction of status epilepticus in mice: development of spontaneous seizures, behavioral alterations and neuronal damage. Eur J Pharmacol 619, 15-24 (2009)

134. I Groticke, K Hoffmann, W Loscher: Behavioral alterations in a mouse model of temporal lobe epilepsy induced by intrahippocampal injection of kainate. Exp Neurol 213, 71-83 (2008)

135. Mde A Furtado, GK Braga, JA Oliveira, F Del Vecchio, N Garcia-Cairasco: Behavioral, morphologic, 
and electroencephalographic evaluation of seizures induced by intrahippocampal microinjection of pilocarpine. Epilepsia 43, S37-39 (2002)

136. FA Scorza, RM Arida, Mda G Naffah-Mazzacoratti, DA Scerni, L Calderazzo, EA Cavalheiro: The pilocarpine model of epilepsy: what have we learned? An Acad Bras Cienc 81, 345-365 (2009)

137. EA Cavalheiro: The pilocarpine model of epilepsy. Ital J Neurol Sci 16, 33-37 (1995)

138. ER Garrido-Sanabria, LF Otalora, MF Arshadmansab, B Herrera, S Francisco, BS Ermolinsky: Impaired expression and function of group II metabotropic glutamate receptors in pilocarpine-treated chronically epileptic rats. Brain Res 1240, 165-176 (2008)

139. B Ermolinsky, MF Arshadmansab, LF Pacheco Otalora, MM Zarei, ER Garrido-Sanabria: Deficit of Kcnmal mRNA expression in the dentate gyrus of epileptic rats. Neuroreport 19, 1291-1294 (2008)

140. ER Garrido Sanabria, MT Castaneda, C Banuelos, MG Perez-Cordova, S Hernandez, LV Colom: Septal GABAergic neurons are selectively vulnerable to pilocarpine-induced status epilepticus and chronic spontaneous seizures. Neuroscience 142, 871-883 (2006)

141. LF Pacheco Otalora, J Couoh, R Shigamoto, MM Zarei, ER Garrido Sanabria: Abnormal mGluR2/3 expression in the perforant path termination zones and mossy fibers of chronically epileptic rats. Brain Res 1098, 170-185 (2006)

142. T Lemos, EA Cavalheiro: Suppression of pilocarpine-induced status epilepticus and the late development of epilepsy in rats. Exp Brain Res 102, 423-428 (1995)

143. G Biagini, E Baldelli, D Longo, L Pradelli, I Zini, MA Rogawski, M Avoli: Endogenous neurosteroids modulate epileptogenesis in a model of temporal lobe epilepsy. Exp Neurol 201, 519-524 (2006)

144. K Goffin, J Nissinen, K Van Laere, A Pitkanen: Cyclicity of spontaneous recurrent seizures in pilocarpine model of temporal lobe epilepsy in rat. Exp Neurol 205, 501-505 (2007)

145. WA Turski, EA Cavalheiro, ZA Bortolotto, LM Mello, M Schwarz, L Turski: Seizures produced by pilocarpine in mice: a behavioral, electroencephalographic and morphological analysis. Brain Res 321, 237-253 (1984)

146. JP Leite, ZA Bortolotto, EA Cavalheiro: Spontaneous recurrent seizures in rats: an experimental model of partial epilepsy. Neurosci Biobehav Rev 14, 511-517 (1990)
147. NY Walton, DM Treiman: Motor and electroencephalographic response of refractory experimental status epilepticus in rats to treatment with MK-801, diazepam, or MK-801 plus diazepam. Brain Res 553, 97-104 (1991)

148. EA Cavalheiro, JP Leite, ZA Bortolotto, WA Turski, C Ikonomidou, L Turski: Long-term effects of pilocarpine in rats: structural damage of the brain triggers kindling and spontaneous recurrent seizures. Epilepsia 32, 778-782 (1991)

149. RM Arida, FA Scorza, CA Peres, EA Cavalheiro: The course of untreated seizures in the pilocarpine model of epilepsy. Epilepsy Res 34, 99-107 (1999)

150. ER Sanabria, H Su, Y Yaari: Initiation of network bursts by $\mathrm{Ca} 2+$-dependent intrinsic bursting in the rat pilocarpine model of temporal lobe epilepsy. J Physiol 532, 205-216 (2001)

151. FE Dudek, TP Sutula: Epileptogenesis in the dentate gyrus: a critical perspective. Prog Brain Res 163, 755-773 (2007)

152. HE Scharfman: The neurobiology of epilepsy. Curr Neurol Neurosci Rep 7, 348-354 (2007)

153. J Engel Jr: Mesial temporal lobe epilepsy: what have we learned? Neuroscientist 7, 340-352 (2001)

154. M Bikson, JE Fox, JG Jefferys: Neuronal aggregate formation underlies spatiotemporal dynamics of nonsynaptic seizure initiation. J Neurophysiol 89, 2330-2333 (2003)

155. GT Finnerty, JG Jefferys: Investigation of the neuronal aggregate generating seizures in the rat tetanus toxin model of epilepsy. J Neurophysiol 88, 2919-2927 (2002)

156. JS Ebersole, AB Chatt: Toward a unified theory of focal penicillin epileptogenesis: an intracortical evoked potential investigation. Epilepsia 22, 347-363 (1981)

157. M Dichter, WA Spencer: Hippocampal penicillin "spike" discharge: epileptic neuron or epileptic aggregate? Neurology $18,282-283$ (1968)

158. CC Young, M Stegen, $\mathrm{R}$ Bernard, $\mathrm{M}$ Muller, J Bischofberger, RW Veh, CA Haas, J Wolfart: Upregulation of inward rectifier $\mathrm{K}+(\mathrm{Kir} 2)$ channels in dentate gyrus granule cells in temporal lobe epilepsy. $J$ Physiol 587, 4213-4233 (2009)

159. M Stegen, CC Young, CA Haas, J Zentner, J Wolfart: Increased leak conductance in dentate gyrus granule cells of temporal lobe epilepsy patients with Ammon's horn sclerosis. Epilepsia 50, 646-653 (2009)

160. RS Winokur, T Kubal, D Liu, SF Davis, BN Smith: Recurrent excitation in the dentate gyrus of a murine model of temporal lobe epilepsy. Epilepsy Res 58, 93-105 (2004) 
161. RS Sloviter: Possible functional consequences of synaptic reorganization in the dentate gyrus of kainatetreated rats. Neurosci Lett 137, 91-96 (1992)

162. MM Okazaki, P Molnar, JV Nadler: Recurrent mossy fiber pathway in rat dentate gyrus: synaptic currents evoked in presence and absence of seizure-induced growth. $J$ Neurophysiol 81, 1645-1660 (1999)

163. LE Mello, EA Cavalheiro, AM Tan, WR Kupfer, JK Pretorius, TL Babb, DM Finch: Circuit mechanisms of seizures in the pilocarpine model of chronic epilepsy: cell loss and mossy fiber sprouting. Epilepsia 34, 985-995 (1993)

164. JE Austin, PS Buckmaster: Recurrent excitation of granule cells with basal dendrites and low interneuron density and inhibitory postsynaptic current frequency in the dentate gyrus of macaque monkeys. J Comp Neurol 476, 205-218 (2004)

165. M Kobayashi, PS Buckmaster: Reduced inhibition of dentate granule cells in a model of temporal lobe epilepsy. $J$ Neurosci 23, 2440-2452 (2003)

166. PS Buckmaster, GF Zhang, R Yamawaki: Axon sprouting in a model of temporal lobe epilepsy creates a predominantly excitatory feedback circuit. $J$ Neurosci 22, 6650-6658 (2002)

167. P Perreault, M Avoli: Physiology and pharmacology of epileptiform activity induced by 4-aminopyridine in rat hippocampal slices. J Neurophysiol 65, 771-785 (1991)

168. OV Godukhin, SG Levin, EY Parnyshkova: The effects of interleukin-10 on the development of epileptiform activity in the hippocampus induced by transient hypoxia, bicuculline, and electrical kindling. Neurosci Behav Physiol 39, 625-631 (2009)

169. RA Voskuyl, H Albus: Spontaneous epileptiform discharges in hippocampal slices induced by 4-aminopyridine. Brain Res 342, 54-66 (1985)

170. T Nagao, A Alonso, M Avoli: Epileptiform activity induced by pilocarpine in the rat hippocampal-entorhinal slice preparation. Neuroscience 72, 399-408 (1996)

171. MS Jensen, Y Yaari: Role of intrinsic burst firing, potassium accumulation, and electrical coupling in the elevated potassium model of hippocampal epilepsy. J Neurophysiol 77, 1224-1233 (1997)

172. MS Jensen, R Azouz, Y Yaari: Variant firing patterns in rat hippocampal pyramidal cells modulated by extracellular potassium. J Neurophysiol 71, 831-839 (1994)

173. MS Jensen, E Cherubini, Y Yaari: Opponent effects of potassium on GABAA-mediated postsynaptic inhibition in the rat hippocampus. J Neurophysiol 69, 764-771 (1993)

174. Y Yaari, A Konnerth, U Heinemann: Nonsynaptic epileptogenesis in the mammalian hippocampus in vitro. II.
Role of extracellular potassium. $J$ Neurophysiol 56, 424438 (1986)

175. EJ Furshpan, DD Potter: Seizure-like activity and cellular damage in rat hippocampal neurons in cell culture. Neuron 3, 199-207 (1989)

176. I Mody, JD Lambert, U Heinemann: Low extracellular magnesium induces epileptiform activity and spreading depression in rat hippocampal slices. J Neurophysiol 57, 869-888 (1987)

177. JH Schneiderman, JF MacDonald: Effects of reduced magnesium on hippocampal synchrony. Brain Res 410, 174-178 (1987)

178. ML Mayer, GL Westbrook, PB Guthrie: Voltagedependent block by $\mathrm{Mg} 2+$ of NMDA responses in spinal cord neurones. Nature 309, 261-263 (1984)

179. L Nowak, P Bregestovski, P Ascher, A Herbet, A Prochiantz: Magnesium gates glutamate-activated channels in mouse central neurones. Nature 307, 462-465 (1984)

180. C Psarropoulou, HL Haas: Action of anticonvulsants on hippocampal slices in Mg-free medium. Naunyn Schmiedebergs Arch Pharmacol 339, 613-616 (1989)

181. AJ Hill, NA Jones, CM Williams, GJ Stephens, BJ Whalley: Development of multi-electrode array screening for anticonvulsants in acute rat brain slices. $J$ Neurosci Methods $185,246-256(2010)$

182. RS Fisher: Animal models of the epilepsies. Brain Res Brain Res Rev 14, 245-278 (1989)

183. S Birnstiel, E Wulfert, SG Beck: Levetiracetam (ucb LO59) affects in vitro models of epilepsy in CA3 pyramidal neurons without altering normal synaptic transmission. Naunyn Schmiedebergs Arch Pharmacol 356, 611-618 (1997)

184. GJ Klapstein, WF Colmers: Neuropeptide Y suppresses epileptiform activity in rat hippocampus in vitro. $J$ Neurophysiol 78, 1651-1661 (1997)

185. B Ault, CM Wang: Adenosine inhibits epileptiform activity arising in hippocampal area CA3. Br J Pharmacol 87, 695-703 (1986)

186. AL Mueller, TV Dunwiddie: Anticonvulsant and proconvulsant actions of alpha- and beta-noradrenergic agonists on epileptiform activity in rat hippocampus in vitro. Epilepsia 24, 57-64 (1983)

187. AP Oliver, BJ Hoffer, RJ Wyatt: The hippocampal slice: a system for studying the pharmacology of seizures and for screening anticonvulsant drugs. Epilepsia 18, 543-548 (1977)

188. F Lehmann-Horn, K Jurkat-Rott: Voltage-gated ion channels and hereditary disease. Physiol Rev 79, 1317-1372 (1999) 
189. RS Kass: The channelopathies: novel insights into molecular and genetic mechanisms of human disease. $J$ Clin Invest 115, 1986-1989 (2005)

190. FM Ashcroft: ATP-sensitive potassium channelopathies: focus on insulin secretion. $J$ Clin Invest 115, 2047-2058 (2005)

191. B Lang, A Vincent: Autoantibodies to ion channels at the neuromuscular junction. Autoimmun Rev 2, 94-100 (2003)

192. OK Steinlein: Genetic mechanisms that underlie epilepsy. Nat Rev Neurosci 5, 400-408 (2004)

193. NA Singh, P Westenskow, C Charlier, C Pappas, J Leslie, J Dillon, VE Anderson, MC Sanguinetti, MF Leppert: KCNQ2 and KCNQ3 potassium channel genes in benign familial neonatal convulsions: expansion of the functional and mutation spectrum. Brain 126, 2726-2737 (2003)

194. SE Heron, HA Phillips, JC Mulley, A Mazarib, MY Neufeld, SF Berkovic, IE Scheffer: Genetic variation of CACNA1H in idiopathic generalized epilepsy. Ann Neurol 55, 595-596 (2004)

195. J Spampanato, A Escayg, MH Meisler, AL Goldin: Functional effects of two voltage-gated sodium channel mutations that cause generalized epilepsy with febrile seizures plus type 2. J Neurosci 21, 7481-7490 (2001)

196. A Gambardella, A Labate, A Giallonardo, U Aguglia: Familial mesial temporal lobe epilepsies: clinical and genetic features. Epilepsia 50, S55-57 (2009)

197. A Gambardella, C Marini: Clinical spectrum of SCN1A mutations. Epilepsia 50, S20-23 (2009)

198. MH Meisler, JA Kearney: Sodium channel mutations in epilepsy and other neurological disorders. J Clin Invest 115, 2010-2017 (2005)

199. S Jung, TD Jones, JN Lugo Jr, AH Sheerin, JW Miller, R D'Ambrosio, AE Anderson, NP Poolos: Progressive dendritic HCN channelopathy during epileptogenesis in the rat pilocarpine model of epilepsy. $J$ Neurosci 27, 13012-13021 (2007)

200. RK Ellerkmann, S Remy, J Chen, D Sochivko, CE Elger, BW Urban, A Becker, H Beck: Molecular and functional changes in voltage-dependent $\mathrm{Na}(+)$ channels following pilocarpine-induced status epilepticus in rat dentate granule cells. Neuroscience 119, 323-333 (2003)

201. AR Brooks-Kayal, MD Shumate, H Jin, TY Rikhter, DA Coulter: Selective changes in single cell GABA (A) receptor subunit expression and function in temporal lobe epilepsy. Nat Med 4, 1166-1172 (1998)

202. JD Graef, BK Nordskog, WF Wiggins, DW Godwin: An acquired channelopathy involving thalamic T-type
Ca2+ channels after status epilepticus. J Neurosci 29, 4430-4441 (2009)

203. G Avanzini, S Franceschetti, M Mantegazza: Epileptogenic channelopathies: experimental models of human pathologies. Epilepsia 48, S51-64 (2007)

204. B Marcelin, L Chauviere, A Becker, M Migliore, M Esclapez, C Bernard: h channel-dependent deficit of theta oscillation resonance and phase shift in temporal lobe epilepsy. Neurobiol Dis 33, 436-447 (2009)

205. JR Naegele: Neuroprotective strategies to avert seizure-induced neurodegeneration in epilepsy. Epilepsia 48, S107-117 (2007)

206. T Deller, CA Haas, TM Freiman, A Phinney, M Jucker, M Frotscher: Lesion-induced axonal sprouting in the central nervous system. Adv Exp Med Biol 557, 101$121(2006)$

207. JM Parent, DH Lowenstein: Seizure-induced neurogenesis: are more new neurons good for an adult brain? Prog Brain Res 135, 121-131 (2002)

208. JM Parent, TW Yu, RT Leibowitz, DH Geschwind, RS Sloviter, DH Lowenstein: Dentate granule cell neurogenesis is increased by seizures and contributes to aberrant network reorganization in the adult rat hippocampus. J Neurosci 17, 3727-3738 (1997)

209. CR Houser: Morphological changes in the dentate gyrus in human temporal lobe epilepsy. Epilepsy Res Suppl 7, 223-234 (1992)

210. JW Geddes, MC Wilson, FD Miller, CW Cotman: Molecular markers of reactive plasticity. Adv Exp Med Biol 268, 425-432 (1990)

211. JE Cavazos, DJ Cross: The role of synaptic reorganization in mesial temporal lobe epilepsy. Epilepsy Behav 8, 483-493 (2006)

212. EW Lothman, EH Bertram $3^{\text {rd }}$ : Epileptogenic effects of status epilepticus. Epilepsia 34, S59-70 (1993)

213. AB Scheibel: Morphological correlates of epilepsy: cells in the hippocampus. Adv Neurol 27, 49-61 (1980)

214. JE Kralic, DA Ledergerber, JM Fritschy: Disruption of the neurogenic potential of the dentate gyrus in a mouse model of temporal lobe epilepsy with focal seizures. Eur $J$ Neurosci 22, 1916-1927 (2005)

215. T Miyazaki, O Miyamoto, NA Janjua, $T$ Hata, F Takahashi, T Itano: Reactive gliosis in areas around third ventricle in association with epileptogenesis in amygdaloidkindled rat. Epilepsy Res 56, 5-15 (2003)

216. HK Wolf, AF Aliashkevich, I Blumcke, OD Wiestler, J Zentner: Neuronal loss and gliosis of the amygdaloid nucleus in temporal lobe epilepsy. A quantitative analysis 
of 70 surgical specimens. Acta Neuropathol 93, 606-610 (1997)

217. G Seifert, G Carmignoto, C Steinhauser: Astrocyte dysfunction in epilepsy. Brain Res Rev 63, 212-221 (2010)

218. A Pitkanen, K Lukasiuk: Molecular and cellular basis of epileptogenesis in symptomatic epilepsy. Epilepsy Behav 14, S16-25 (2009)

219. R Jabs, G Seifert, C Steinhauser: Astrocytic function and its alteration in the epileptic brain. Epilepsia 49, S3-12 (2008)

220. DK Binder, C Steinhauser: Functional changes in astroglial cells in epilepsy. Glia 54, 358-368 (2006)

221. C Kendal, I Everall, C Polkey, S Al-Sarraj: Glial cell changes in the white matter in temporal lobe epilepsy. Epilepsy Res 36, 43-51 (1999)

222. SA Baxendale, W Van Paesschen, PJ Thompson, JS Duncan, WF Harkness, SD Shorvon: Hippocampal cell loss and gliosis: relationship to preoperative and postoperative memory function. Neuropsychiatry Neuropsychol Behav Neurol 11, 12-21 (1998)

223. DV Lewis: Losing neurons: selective vulnerability and mesial temporal sclerosis. Epilepsia 46, S39-44 (2005)

224. S Waldbaum, M Patel: Mitochondria, oxidative stress, and temporal lobe epilepsy. Epilepsy Res 88, 2345 (2010)

225. S Xu, Q Pang, Y Liu, W Shang, G Zhai, M Ge: Neuronal apoptosis in the resected sclerotic hippocampus in patients with mesial temporal lobe epilepsy. J Clin Neurosci 14, 835-840 (2007)

226. DG Fujikawa: Neuronal death in mesial temporal sclerosis: separating morphology from mechanism. Epilepsia 44, 1607 (2003)

227. H Uysal, IU Cevik, F Soylemezoglu, B Elibol, YG Ozdemir, T Evrenkaya, S Saygi, T Dalkara: Is the cell death in mesial temporal sclerosis apoptotic? Epilepsia 44, 778-784 (2003)

228. J Choi, DR Nordli Jr, TD Alden, A DiPatri Jr, L Laux, K Kelley, J Rosenow, SU Schuele, V Rajaram, S Koh: Cellular injury and neuroinflammation in children with chronic intractable epilepsy. $J$ Neuroinflammation 6, 38 (2009).

229. L Bernardino, R Ferreira, AJ Cristovao, F Sales, JO Malva: Inflammation and neurogenesis in temporal lobe epilepsy. Curr Drug Targets CNS Neurol Disord 4, 349360 (2005)

230. DM Kullmann: The neuronal channelopathies. Brain 125, 1177-1195 (2002)
231. LJ Ptacek, YH Fu: Channelopathies: episodic disorders of the nervous system. Epilepsia 42, S35-43 (2001)

232. H Lerche, $\mathrm{K}$ Jurkat-Rott, $\mathrm{F}$ Lehmann-Horn: Ion channels and epilepsy. Am J Med Genet 106, 146-159 (2001)

233. M Li, HA Lester: Ion channel diseases of the central nervous system. CNS Drug Rev 7, 214-240 (2001)

234. EF Bond: Channelopathies: potassium-related periodic paralyses and similar disorders. AACN Clin Issues 11, 261$270(2000)$

235. GG Celesia: Disorders of membrane channels or channelopathies. Clin Neurophysiol 112, 2-18 (2001)

236. MA Rogawski: KCNQ2/KCNQ3 K+ channels and the molecular pathogenesis of epilepsy: implications for therapy. Trends Neurosci 23, 393-398 (2000)

237. OK Steinlein, JL Noebels: Ion channels and epilepsy in man and mouse. Curr Opin Genet Dev 10, 286-291 (2000)

238. YY Wang, P Smith, M Murphy, M Cook: Global Expression Profiling in Epileptogenesis: Does It Add to the Confusion? Brain Pathol 20, 1-16 (2010)

239. MH Meisler, J Kearney, R Ottman, A Escayg: Identification of epilepsy genes in human and mouse. Annu Rev Genet 35, 567-588 (2001)

240. BS Meldrum, MA Rogawski: Molecular targets for antiepileptic drug development. Neurotherapeutics 4, 18-61 (2007)

241. MA Rogawski, W Loscher: The neurobiology of antiepileptic drugs. Nat Rev Neurosci 5, 553-564 (2004)

242. GA Gutman, KG Chandy, S Grissmer, M Lazdunski, D McKinnon, LA Pardo, GA Robertson, B Rudy, MC Sanguinetti, W Stuhmer, X Wang: International Union of Pharmacology. LIII. Nomenclature and molecular relationships of voltage-gated potassium channels. Pharmacol Rev 57, 473-508 (2005)

243. SA Goldstein, DA Bayliss, D Kim, F Lesage, LD Plant, S Rajan. International Union of Pharmacology. LV. Nomenclature and molecular relationships of two-P potassium channels. Pharmacol Rev 57, 527-540 (2005)

244. Y Kubo, JP Adelman, DE Clapham, LY Jan, A Karschin, Y Kurachi, M Lazdunski, CG Nichols, S Seino, CA Vandenberg: International Union of Pharmacology. LIV. Nomenclature and molecular relationships of inwardly rectifying potassium channels. Pharmacol Rev 57, 509-526 (2005)

245. AD Wei, GA Gutman, R Aldrich, KG Chandy, S Grissmer, H Wulff: International Union of Pharmacology. 
LII. Nomenclature and molecular relationships of calciumactivated potassium channels. Pharmacol Rev 57, 463-472 (2005)

246. A Mathie, JR Wooltorton, CS Watkins: Voltageactivated potassium channels in mammalian neurons and their block by novel pharmacological agents. Gen Pharmacol 30, 13-24 (1998)

247. MJ Christie: Molecular and functional diversity of $\mathrm{K}+$ channels. Clin Exp Pharmacol Physiol 22, 944-951 (1995)

248. O Pongs: Regulation of excitability by potassium channels. Results Probl Cell Differ 44, 145-161 (2008)

249. L Feinshreiber, D Singer-Lahat, U Ashery, I Lotan: Voltage-gated potassium channel as a facilitator of exocytosis. Ann N Y Acad Sci 1152, 87-92 (2009)

250. G Edwards, AH Weston: The role of potassium channels in excitable cells. Diabetes Res Clin Pract 28, S57-66 (1995)

251. MM Monaghan, M Menegola, H Vacher, KJ Rhodes, JS Trimmer: Altered expression and localization of hippocampal A-type potassium channel subunits in the pilocarpine-induced model of temporal lobe epilepsy. Neuroscience 156, 550-562 (2008)

252. T Su, WD Cong, YS Long, AH Luo, WW Sun, WY Deng, WP Liao: Altered expression of voltage-gated potassium channel 4.2 and voltage-gated potassium channel 4-interacting protein, and changes in intracellular calcium levels following lithium-pilocarpine-induced status epilepticus. Neuroscience 157, 566-576 (2008)

253. SM Lee, JE Kim, JH Sohn, HC Choi, JS Lee, SH Kim, MJ Kim, IG Choi, TC Kang: Down-regulation of delayed rectifier $\mathrm{K}(+)$ channels in the hippocampus of seizure sensitive gerbils. Brain Res Bull 80, 433-442 (2009)

254. LL Yuan, JP Adams, M Swank, JD Sweatt, D Johnston: Protein kinase modulation of dendritic $\mathrm{K}+$ channels in hippocampus involves a mitogen-activated protein kinase pathway. $J$ Neurosci $22,4860-4868$ (2002)

255. B Singh, I Ogiwara, M Kaneda, N Tokonami, E Mazaki, K Baba, K Matsuda, Y Inoue, K Yamakawa: A Kv4.2 truncation mutation in a patient with temporal lobe epilepsy. Neurobiol Dis 24, 245-253 (2006)

256. E Yus-Najera, A Munoz, N Salvador, BS Jensen, HB Rasmussen, J Defelipe, A Villarroel: Localization of KCNQ5 in the normal and epileptic human temporal neocortex and hippocampal formation. Neuroscience 120, 353-364 (2003)

257. JJ Lawrence, F Saraga, JF Churchill, JM Statland, KE Travis, FK Skinner, CJ McBain: Somatodendritic $\mathrm{Kv} 7 / \mathrm{KCNQ} / \mathrm{M}$ channels control interspike interval in hippocampal interneurons. J Neurosci 26, 12325-12338 (2006)
258. JJ Luszczki. Third-generation antiepileptic drugs: mechanisms of action, pharmacokinetics and interactions. Pharmacol Rep 61, 197-216 (2009)

259. L Tatulian, $\mathrm{P}$ Delmas, FC Abogadie, DA Brown: Activation of expressed KCNQ potassium currents and native neuronal M-type potassium currents by the anticonvulsant drug retigabine. J Neurosci 21, 5535-5545 (2001)

260. MC Walker, JW Sander: New anti-epileptic drugs. Expert Opin Investig Drugs 8, 1497-1510 (1999)

261. ES Faber: Functions and modulation of neuronal SK channels. Cell Biochem Biophys 55, 127-139 (2009)

262. ES Faber, P Sah: Functions of SK channels in central neurons. Clin Exp Pharmacol Physiol 34, 1077-1083 (2007)

263. P Pedarzani, M Stocker: Molecular and cellular basis of small--and intermediate-conductance, calcium-activated potassium channel function in the brain. Cell Mol Life Sci 65, 3196-3217 (2008)

264. VK Gribkoff, JE Starrett Jr, SI Dworetzky: Maxi-K potassium channels: form, function, and modulation of a class of endogenous regulators of intracellular calcium. Neuroscientist 7, 166-177 (2001)

265. P Sah, P Davies: Calcium-activated potassium currents in mammalian neurons. Clin Exp Pharmacol Physiol 27, 657-663 (2000)

266. W Du, JF Bautista, H Yang, A Diez-Sampedro, SA You, L Wang, P Kotagal, HO Luders, J Shi, J Cui, GB Richerson, QK Wang: Calcium-sensitive potassium channelopathy in human epilepsy and paroxysmal movement disorder. Nat Genet 37, 733-738 (2005)

267. R Brenner, QH Chen, A Vilaythong, GM Toney, JL Noebels, RW Aldrich: BK channel beta4 subunit reduces dentate gyrus excitability and protects against temporal lobe seizures. Nat Neurosci 8, 1752-1759 (2005)

268. LF Pacheco Otalora, EF Hernandez, MF Arshadmansab, S Francisco, M Willis, B Ermolinsky, M Zarei, HG Knaus, ER Garrido-Sanabria: Downregulation of BK channel expression in the pilocarpine model of temporal lobe epilepsy. Brain Res 1200, 116131 (2008)

269. MS Oliveira, F Skinner, MF Arshadmansab, I Garcia, CF Mello, HG Knaus, BS Ermolinsky, LF Otalora, ER Garrido-Sanabria: Altered expression and function of small-conductance (SK) $\mathrm{Ca}(2+)$-activated $\mathrm{K}+$ channels in pilocarpine-treated epileptic rats. Brain Res 1348, 187-199 (2010)

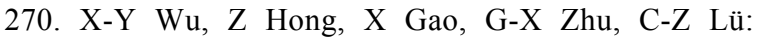
Alterations in KCNJ4 gene expression in human 
temporal lobe epilepsy. Chin J Neurol 39, 242-245 (2006)

271. L Xu, X-Y Wu, Z Hong: Dynamic changes of Kir2. 3 mRNA in the hippocampus of rats with chronic temporal lobe epilepsy. Fudan University J Med Sci 36, 427-430 (2009)

272. JE Kim, SE Kwak, SY Choi, TC Kang: Regionspecific alterations in astroglial TWIK-related acidsensitive $\mathrm{K}+-1$ channel immunoreactivity in the rat hippocampal complex following pilocarpine-induced status epilepticus. J Comp Neurol 510, 463-474 (2008)

273. JE Kim, SE Kwak, TC Kang: Upregulated TWIKrelated acid-sensitive $\mathrm{K}+$ channel- 2 in neurons and perivascular astrocytes in the hippocampus of experimental temporal lobe epilepsy. Epilepsia 50, 654-663 (2009)

274. Y Wang, B Xiao, X-S Yang, X-Y Long, S-Y Li, G-L Li, J-H Liang: Altered expression of $\mathrm{G}$ protein-coupled inwardly rectifier potassium channels subunit 2 (GIRK2) in hippocampus of temporal epileptic rat induced by kainic acid. Chin J Neurol 37, 224-227 (2004)

275. WA Catterall, AL Goldin, SG Waxman: International Union of Pharmacology. XLVII. Nomenclature and structure-function relationships of voltage-gated sodium channels. Pharmacol Rev 57, 397-409 (2005)

276. N Agrawal, A Alonso, DS Ragsdale: Increased persistent sodium currents in rat entorhinal cortex layer $\mathrm{V}$ neurons in a post-status epilepticus model of temporal lobe epilepsy. Epilepsia 44, 1601-1604 (2003)

277. C Yue, S Remy, H Su, H Beck, Y Yaari: Proximal persistent $\mathrm{Na}+$ channels drive spike afterdepolarizations and associated bursting in adult CA1 pyramidal cells. $J$ Neurosci 25, 9704-9720 (2005)

278. WR Whitaker, RL Faull, M Dragunow, EW Mee, PC Emson, JJ Clare: Changes in the mRNAs encoding voltagegated sodium channel types II and III in human epileptic hippocampus. Neuroscience 106, 275-285 (2001)

279. Z Chen, S Chen, L Chen, J Zhou, Q Dai, L Yang, X Li, L Zhou: Long-term increasing co-localization of SCN8A and ankyrin-G in rat hippocampal cornu ammonis 1 after pilocarpine induced status epilepticus. Brain Res $1270,112-120$ (2009)

280. F Bartolomei, M Gastaldi, A Massacrier, R Planells, S Nicolas, P Cau: Changes in the mRNAs encoding subtypes I, II and III sodium channel alpha subunits following kainate-induced seizures in rat brain. $J$ Neurocytol 26, 667678 (1997)

281. E Aronica, D Troost, AJ Rozemuller, B Yankaya, GH Jansen, LL Isom, JA Gorter: Expression and regulation of voltage-gated sodium channel betal subunit protein in human gliosis-associated pathologies. Acta Neuropathol 105, 515-523 (2003)
282. KL van Gassen, M de Wit, M van Kempen, WS van der Hel, PC van Rijen, AP Jackson, D Lindhout, PN de Graan: Hippocampal Nabeta3 expression in patients with temporal lobe epilepsy. Epilepsia 50, 957-962 (2009)

283. KL van Gassen, $M$ de Wit, MJ Koerkamp, MG Rensen, PC van Rijen, FC Holstege, D Lindhout, PN de Graan: Possible role of the innate immunity in temporal lobe epilepsy. Epilepsia 49, 1055-1065 (2008)

284. C Schaub, M Uebachs, H Beck: Diminished response of CA1 neurons to antiepileptic drugs in chronic epilepsy. Epilepsia 48, 1339-1350 (2007)

285. K Jandova, D Pasler, LL Antonio, C Raue, S Ji, M Njunting, O Kann, R Kovacs, HJ Meencke, EA Cavalheiro, U Heinemann, S Gabriel, TN Lehmann: Carbamazepineresistance in the epileptic dentate gyrus of human hippocampal slices. Brain 129, 3290-3306 (2006)

286. S Remy, S Gabriel, BW Urban, D Dietrich, TN Lehmann, CE Elger, U Heinemann, H Beck: A novel mechanism underlying drug resistance in chronic epilepsy. Ann Neurol 53, 469-479 (2003)

287. WA Catterall, E Perez-Reyes, TP Snutch, J Striessnig: International Union of Pharmacology. XLVIII. Nomenclature and structure-function relationships of voltage-gated calcium channels. Pharmacol Rev 57, 411-425 (2005)

288. BP Bean: The action potential in mammalian central neurons. Nat Rev Neurosci 8, 451-465 (2007)

289. AJ Becker, J Pitsch, D Sochivko, T Opitz, M Staniek, CC Chen, KP Campbell, S Schoch, Y Yaari, H Beck: Transcriptional upregulation of Cav3.2 mediates epileptogenesis in the pilocarpine model of epilepsy. $J$ Neurosci 28, 13341-13353 (2008)

290. JH Xu, L Long, YC Tang, HT Hu, FR Tang: Ca (v)1.2, $\mathrm{Ca}(\mathrm{v}) 1.3$, and $\mathrm{Ca}(\mathrm{v}) 2.1$ in the mouse hippocampus during and after pilocarpine-induced status epilepticus. Hippocampus 17, 235-251 (2007)

291. S Vigues, M Gastaldi, C Chabret, A Massacrier, P Cau, J Valmier: Regulation of calcium channel alpha (1A) subunit splice variant mRNAs in kainate-induced temporal lobe epilepsy. Neurobiol Dis 6, 288-301 (1999)

292. A Djamshidian, R Grassl, M Seltenhammer, T Czech, C Baumgartner, M Schmidbauer, W Ulrich, F Zimprich: Altered expression of voltage-dependent calcium channel alpha (1) subunits in temporal lobe epilepsy with Ammon's horn sclerosis. Neuroscience 111, 57-69 (2002)

293. AA Lie, I Blumcke, SG Volsen, OD Wiestler, CE Elger, H Beck: Distribution of voltage-dependent calcium channel beta subunits in the hippocampus of patients with temporal lobe epilepsy. Neuroscience 93, 449-456 (1999)

294. RA Bender, SV Soleymani, AL Brewster, ST Nguyen, H Beck, GW Mathern, TZ Baram: Enhanced expression of 
a specific hyperpolarization-activated cyclic nucleotidegated cation channel $(\mathrm{HCN})$ in surviving dentate gyrus granule cells of human and experimental epileptic hippocampus. J Neurosci 23, 6826-6836 (2003)

295. KL Powell, C Ng, TJ O'Brien, SH Xu, DA Williams, SJ Foote, CA Reid: Decreases in HCN mRNA expression in the hippocampus after kindling and status epilepticus in adult rats. Epilepsia 49, 1686-1695 (2008)

296. U Strauss, MH Kole, AU Brauer, J Pahnke, R Bajorat, A Rolfs, R Nitsch, RA Deisz: An impaired neocortical $\mathrm{Ih}$ is associated with enhanced excitability and absence epilepsy. Eur J Neurosci 19, 3048-3058 (2004)

297. T Budde, L Caputi, T Kanyshkova, R Staak, C Abrahamczik, T Munsch, HC Pape: Impaired regulation of thalamic pacemaker channels through an imbalance of subunit expression in absence epilepsy. $J$ Neurosci 25, 9871-9882 (2005)

298. K Chen, I Aradi, N Thon, M Eghbal-Ahmadi, TZ Baram, I Soltesz: Persistently modified h-channels after complex febrile seizures convert the seizure-induced enhancement of inhibition to hyperexcitability. Nat Med 7, 331-337 (2001)

299. M Kuisle, N Wanaverbecq, AL Brewster, SG Frere, D Pinault, TZ Baram, A Luthi: Functional stabilization of weakened thalamic pacemaker channel regulation in rat absence epilepsy. $J$ Physiol 575, 83-100 (2006)

300. F Hofmann, M Biel, UB Kaupp: International Union of Pharmacology. LI. Nomenclature and structure-function relationships of cyclic nucleotideregulated channels. Pharmacol Rev 57, 455-462 (2005)

301. M Biel, C Wahl-Schott, S Michalakis, X Zong: Hyperpolarization-activated cation channels: from genes to function. Physiol Rev 89, 847-885 (2009)

302. RB Robinson, SA Siegelbaum: Hyperpolarizationactivated cation currents: from molecules to physiological function. Annu Rev Physiol 65, 453-480 (2003)

303. M Shin, D Brager, TC Jaramillo, D Johnston, DM Chetkovich: Mislocalization of $h$ channel subunits underlies $\mathrm{h}$ channelopathy in temporal lobe epilepsy. Neurobiol Dis 32, 26-36 (2008)

304. MM Shah, AE Anderson, V Leung, X Lin, D Johnston: Seizure-induced plasticity of $\mathrm{h}$ channels in entorhinal cortical layer III pyramidal neurons. Neuron 44, 495-508 (2004)

305. D Tsay, JT Dudman, SA Siegelbaum: HCN1 channels constrain synaptically evoked $\mathrm{Ca} 2+$ spikes in distal dendrites of CA1 pyramidal neurons. Neuron 56, 1076-1089 (2007)
306. JC Magee: Dendritic hyperpolarization-activated currents modify the integrative properties of hippocampal CA1 pyramidal neurons. J Neurosci 18, 7613-7624 (1998)

307. G Stuart, N Spruston: Determinants of voltage attenuation in neocortical pyramidal neuron dendrites. $J$ Neurosci 18, 3501-3510 (1998)

308. M Kitayama, H Miyata, M Yano, N Saito, Y Matsuda, T Yamauchi, S Kogure: Ih blockers have a potential of antiepileptic effects. Epilepsia 44, 20-24 (2003)

309. PA Schwartzkroin, DA Prince: Cellular and field potential properties of epileptogenic hippocampal slices. Brain Res 147, 117-130 (1978)

310. S Otoom, LM Tian, KA Alkadhi: Veratridine-treated brain slices: a cellular model for epileptiform activity. Brain Res 789, 150-156 (1998)

311. S Piredda, W Yonekawa, TS Whittingham, HJ Kupferberg: Effects of antiepileptic drugs on pentylenetetrazole-induced epileptiform activity in the in vitro hippocampus. Epilepsia 27, 341-346 (1986)

312. A Konnerth, U Heinemann, Y Yaari: Nonsynaptic epileptogenesis in the mammalian hippocampus in vitro. I. Development of seizurelike activity in low extracellular calcium. J Neurophysiol 56, 409-423 (1986)

313. I Nelken, Y Yaari: The role of interstitial potassium in the generation of low-calcium hippocampal seizures. Isr $J$ Med Sci 23, 124-131 (1987)

314. G Nyitrai, B Lasztoczi, J Kardos: Glutamate uptake shapes low-Mg2+) induced epileptiform activity in juvenile rat hippocampal slices. Brain Res 1309, 172-178 (2010)

315. R Gutierrez, V Armand, S Schuchmann, U Heinemann: Epileptiform activity induced by low $\mathrm{Mg} 2+$ in cultured rat hippocampal slices. Brain Res 815, 294-303 (1999)

316. L Velisek, JP Dreier, PK Stanton, U Heinemann, SL Moshe: Lowering of extracellular $\mathrm{pH}$ suppresses low-Mg $(2+)$-induces seizures in combined entorhinal cortexhippocampal slices. Exp Brain Res 101, 44-52 (1994)

317. J Tian, Y Li, S Yang: Model of stimulus train-induced bursting in rat hippocampal slice and the effect of Lglutamate on it). Hua Xi Yi Ke Da Xue Xue Bao 22, 27-30 (1991)

318. PW Gean, P Shinnick-Gallagher: Characterization of the epileptiform activity induced by magnesium-free solution in rat amygdala slices: an intracellular study. Exp Neurol 101, 248-255 (1988)

319. SF Traynelis, R Dingledine: Potassium-induced spontaneous electrographic seizures in the rat hippocampal slice. J Neurophysiol 59, 259-276 (1988) 
320. PA Rutecki, FJ Lebeda, D Johnston: 4-Aminopyridine produces epileptiform activity in hippocampus and enhances synaptic excitation and inhibition. $J$ Neurophysiol 57, 1911-1924 (1987)

321. E Aitchison, SE Weston, A Constanti, BJ Whalley: Anticholinesterase-induced epileptiform activity in immature rat piriform cortex slices, in vitro. Neurosci Lett $473,252-256$ (2010)

322. PK Harrison, RD Sheridan, AC Green, IR Scott, JE Tattersall: A guinea pig hippocampal slice model of organophosphate-induced seizure activity. J Pharmacol Exp Ther 310, 678-686 (2004)

323. MR Pelletier, PL Carlen: Repeated tetanic stimulation in piriform cortex in vitro: epileptogenesis and pharmacology. J Neurophysiol 76, 4069-4079 (1996)

324. P Varro, R Szemerszky, G Bardos, I Vilagi: Changes in synaptic efficacy and seizure susceptibility in rat brain slices following extremely low-frequency electromagnetic field exposure. Bioelectromagnetics 30, 631-640 (2009)

325. AJ Lombardo, R Kuzniecky, RE Powers, GB Brown: Altered brain sodium channel transcript levels in human epilepsy. Brain Res Mol Brain Res 35, 84-90 (1996)

326. S Penschuck, JF Bastlund, HS Jensen, TB Stensbol, J Egebjerg, WP Watson: Changes in KCNQ2 immunoreactivity in the amygdala in two rat models of temporal lobe epilepsy. Brain Res Mol Brain Res 141, 66$73(2005)$

Key Words Epilepsy, Channelopathy, Electrophysiology, Pilocarpine, Voltage-gated ion channel, Review

Send correspondence to: Emilio R. Garrido Sanabria, Department of Biological Sciences, 80 Fort Brown, Brownsville, Texas 78520, Tel: 956-882-5053, Fax: 956882-5043, E-mail: emilio.garrido@utb.edu

http://www.bioscience.org/current/vol3S.htm 